\title{
NON-CONSENSUAL SECURITY INTERESTS IN PERSONAL PROPERTY
}

\author{
RODERICK J. WOOD \\ MICHAEL I. WYLIE**
}

The authors trace the chaotic growth of nonconsensual security interests in personal property. Rules governing non-consensual security interests are analyzed and show'n to have developed in an inconsistem and unpredictable mamer. The authors set out a framen'ork to resolve the priority contests between security interests governed by the Personal Property Security Act and non-consensual security interests. Ultimately, the authors call for reform to this area of the law', similar to that which occurred to chattel security law with the advent of the Personal Property Security Act. so as to create some degree of predictability in the area.
Les auteurs suivent la croissance chaotique des sûretés non consensuelles relatives aux biens personnels. Les règles qui les régissent ont été élaborées de façon incohéremte et imprévisible. Les auteurs établissent un cadre permettant de résoudre les conflits de priorités entre les sîretés régies par la loi sur les suiretés mobilières relatives aut biens personnels et les sûretés non consensuelles. Finalement, les auteurs réclament des réformes similaires dans ce secteur du droit à celles qui ont déjà eu lieu en matière de garanties mobilières avec Iadoption de la PPSA, afin de créer une certaine mesure de prévisibilité dans le domaine.

\section{TABLE OF CONTENTS}

I. INTRODUCTION ..................... 1056

II. SOURCES OF NON-CONSENSUAL

SECURITY LAW ...................... 1057

A. LIENS . . . . . . . . . . . . . . . . . . . . . 1057

B. RIGHTS OF DISTRESS . . . . . . . . . . . . . . . . 1059

C. STATUTORY CHARGES AND

SECURITY INTERESTS . . . . . . . . . . . . . 1061

D. DEEMED STATUTORY TRUSTS $\ldots \ldots \ldots \ldots \ldots \ldots 1062$

E. STATUTORY DEMANDS ................. 1063

F. STATUTORY JUDGMENTS AND

STATUTORY PREFERENCES $\ldots \ldots \ldots \ldots \ldots \ldots \ldots 1063$

III. APPLICATION OF THE PPSA . . . . . . . . . . . . . . 1064

IV. PARAMETERS OF THE NON-CONSENSUAL

SECURITY INTEREST $\ldots \ldots \ldots \ldots \ldots \ldots \ldots \ldots \ldots \ldots$

A. SUBJECT MATTER OF THE

NON-CONSENSUAL SECURITY INTEREST . . . . . . 1067

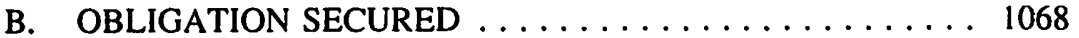

C. FORMAL REQUIREMENTS $\ldots \ldots \ldots \ldots \ldots \ldots \ldots \ldots 1068$

D. TIME OF ATTACHMENT $\ldots \ldots \ldots \ldots \ldots \ldots \ldots 1069$

E. PERFECTION REQUIREMENTS . . . . . . . . . . 1070

F. TERMINATION OF THE

NON-CONSENSUAL SECURITY INTEREST . . . . . . . 1071

V. OVERLAP BETWEEN CONSENSUAL

AND NON-CONSENSUAL SECURITY INTERESTS . . . . . . 1071 
VI. RESOLUTION OF PRIORITY

COMPETITIONS BETWEEN PPSA SECURITY INTERESTS

AND NON-CONSENSUAL SECURITY INTERESTS . . . . . . 1072

A. OVERVIEW ........................ 1072

B. PRIORITY RULES CONTAINED

IN THE PPSA . . . . . . . . . . . . . . . . . . . 1073

C. NON-PPSA LEGISLATIVE AND

COMMON LAW PRIORITY RULES . . . . . . . . . . . 1078

D. ORDER OF ATTACHMENT $\ldots \ldots \ldots \ldots \ldots \ldots \ldots \ldots 1081$

E. PRIORITY STATUS OF

NON-CONSENSUAL SECURITY INTERESTS . . . . . . . 1083

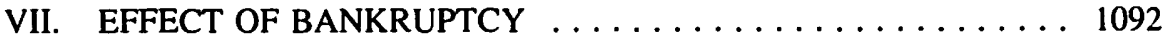

A. THE ORIGINAL APPROACH OF THE

BANKRUPTCY ACT . . . . . . . . . . . . . 1092

B. THE 1992 BANKRUPTCY AMENDMENTS . . . . . . . 1095

VIII. CONCLUSION ........................ 1098

\section{INTRODUCTION}

Our objective is to develop a legal framework for the resolution of a priority competition between a personal property security interest and a lien or other nonconsensual security device. The Alberta Personal Property Security Act' (hereafter the "PPSA") contains a comprehensive set of internal priority rules which govern priority disputes between competing provincial security interests in the same collateral. These rules do not apply where the competition is between a security interest and some other interest that is not a security interest within the meaning of the PPSA. The PPSA provides some priority rules for such situations, but does not provide an exhaustive set of rules for all contests that may arise. Supplementary principles must be supplied in order to fill in the gaps so as to produce a complete priority resolving mechanism. We shall examine the relevant provisions of the PPSA and the other supplementary legal principles which together provide the means of resolving priority competitions where a lien or other non-consensual security interest is involved.

An initial difficulty concerns the use of terminology. There are common law and statutory liens, rights of distress, statutory charges, deemed trusts and statutory demands, all of which may come into competition with a PPSA security interest. These devices will be collectively referred to as non-consensual security interests. A non-consensual security interest creates an interest in the property of the debtor that secures payment or performance of an obligation. Unlike a PPSA security interest, a non-consensual security interest comes into being by operation of law rather than through the agreement of the parties.

In any priority competition, a number of preliminary matters should be considered before a priority rule is applied. For example, in a priority competition between two 
consensual security interests governed by the PPSA, it is necessary to determine if the security interests are enforceable, if they have attached and if they have been perfected. Different preliminary matters must be addressed where the competing interest is a nonconsensual security interest. It is first necessary to identify the source of law that governs the non-consensual security interest, and to determine if the device is in fact an unconventional form of security interest that is within the scope of the PPSA. If the device is found to be a true non-consensual security interest, its legal parameters (or defining features) must be established. For example, it is crucial to ascertain what property is subject to the non-consensual security interest, what obligations are secured by it and what steps are needed to validate or protect it. A holder of a non-consensual security interest may have been granted a consensual security interest to secure the same obligation, and the legal consequences of this must be determined. We shall begin with a discussion of these preliminary considerations. We will then develop a framework for analysing priority competitions between a security interest governed by the PPSA and a non-consensual security interest. We shall apply this analytical framework to the different forms of non-consensual security interests. Finally, we shall consider the effect of bankruptcy on the question of priorities.

\section{SOURCES OF NON-CONSENSUAL SECURITY LAW}

\section{A. LIENS}

The common law lien gives a lienholder a right to retain property of another until an obligation is satisfied. ${ }^{2}$ It is a possessory lien, which means that the retention of possession of the property by the lienholder is necessary for the continued existence of the lien. Re-delivery of the goods to the debtor destroys the lien, ${ }^{3}$ and it does not revive upon a recovery of possession by the lienholder ${ }^{4}$ If the debtor agrees to hold the goods as bailee of the lienholder, a re-delivery of the goods to the debtor does not result in the loss of the ien. ${ }^{5}$

A distinction is drawn between particular liens and general liens. ${ }^{6}$ A particular lien gives the lienholder the right to retain goods to secure payment of charges for services provided in relation to those goods. A general lien gives the lienholder the right to retain the goods to secure charges other than those relating to the goods retained (such as for previous charges in respect of goods that have been returned to the debtor). All of the common law liens which arise by operation of law are particular liens. Innkeepers and common carriers were favoured with such liens because they operated in common callings

Hammonds v. Barclay (1801), 2 East 227, 102 E.R. 356; Arnold Brothers Transport Lid. v. Cawthorne Auction Services Lid. (1978), 8 Alta. L.R. (2d) 250 at 251 (Dist. Ct.).

3. Jones v. Peale (1736), I Str. 557, 93 E.R. 698. The lien is not lost if the possession is retaken without permission or by fraudulent means: Coutts Machinery Co. Lid. v. Richards (1986), 71 A.R. 232 (M.C.); Wallace v. Woodgate (1824), 1 Car. \& P. 575, 171 E.R. 1323.

4. Re Lehner (1985), 4 P.P.S.A.C. 254 (Sask. Q.B.): Pennington v. Reliance Motor Works Lid., [1923] 1 K.B. 127.

s. Albemarle Supply Co. Lid. v. Hind \& Co., [1928] 1 K.B. 307 (C.A.); J.H. Early Motor Co. Ltd. v. Siekawitch, [1931] 3 W.W.R. 521 (Sask. C.A.). And see discussion, infra, at notes 106-107.

6. Senft v. Bank of Montreal (1986), 69 A.R. 35 (Q.B.). 
in which they were required by law to receive the goods. ${ }^{7}$ The common law also conferred a lien in favour of a person who performed work that improved the goods. The lien only arose if there was an enhancement in value of the goods as a result of the work. Therefore, a lien was not available for the maintenance or storage of goods ${ }^{8}$ or the feeding and keeping of animals. ${ }^{9}$ The common law liens were passive liens. They gave the lienholder the right to retain the goods, but did not give the lienholder the right to sell them and recover the charges out of the proceeds of sale. ${ }^{10}$

A lien may also arise out of contract. The agreement to create the lien may be express, or it could be implied by virtue of a course of dealings or a trade usage." General liens do not arise out of operation of law, but must be founded upon an express agreement or implied from a usage of trade. ${ }^{12}$ General liens arising out of usage have been established in the case of factors, bankers, stockbrokers and solicitors. ${ }^{13}$

By the middle of the nineteenth century, a coherent body of law governing possessory liens had been largely developed. The next stage in the development of the law was overwhelmingly statutory in character. The first statutes used the possessory lien as their basic model, but were designed to extend the law in two directions. First, many of the liens were converted from passive liens to active liens by the creation of a statutory right to sell the goods. ${ }^{14}$ Second, the categories of claimants entitled to claim a lien were expanded by legislation which created particular liens in favour of parties who were not entitled to liens under common law. Statutory liens were enacted in favour of livery stable keepers and warehouse keepers who were not formerly entitled to claim a lien because they did not improve the goods. ${ }^{15}$ Many of the common law liens were placed on a statutory footing as an incidental consequence of this process. This legislative

Robins \& Co. v. Gray, [1895] 2 Q.B. 501 (C.A.).

Hatton v. Car Maintenance Co. Ltd., [1915] 1 Ch. 621.

Morrison v. Bryan (1909), 12 W.L.R. 415 (Sask. Dist. Ct.) (agister not entitled to a lien at common law for feeding of animals because no improvement of animal involved).

Mulliner v. Florence (1878), 3 Q.B.D. 484 (C.A.) (innkeeper liable in conversion for wrongful sale of goods subject to a lien). The same approach was adopted in respect of statutory liens if the statute did not set out a procedure for sale: Prinneveau v. Morden (1913), 4 W.W.R. 637 (Alta. S.C.T.D.). Gladstone v. Birley (1817), 2 Mer. 401, 35 E.R. 993.

Trotrier v. Red River Transportation Co., [1875-83] Man. R. 255, at 261-2 (Q.B.); Senfi v. Bank of Montreal, supra, note 6.

Cowell v. Simpson (1809), 16 Ves. 275, 33 E.R. 989 (factors); Brando v. Barnett (1846), 12 Cl. \& F. 787, 8 E.R. 1622 (bankers); Re London and Glohe Finance Corp., [1902] 2 Ch. 416 (stockbrokers); Ex parte Sterling (1809), 16 Ves. 258, 33 E.R. 982 (solicitors). For solicitors, the general lien is the retaining lien that allows solicitors to retain property until outstanding fees are paid. The charge that solicitors have over property recovered or preserved is a particular lien. See Alberta Rules of Court, Rule 625 and Halsbury's Law's of England, 4th ed., vol. 44 (London: Butterworths, 1979) at 178.

Hotelkeepers" Ordinance, O.N.W.T. 1884, No. 34, sec now Innkeepers Act, R.S.A. 1980, c. 1-4; Mechanics' Lien Ordinance, O.N.W.T. 1889, No. 5, s.31 conferred a statutory right of sale in relation to anificers' liens. The provision in the Mechanics' Lien Act was superseded in 1921 by the Possessory Liens Act, infra, note 16.

Livery Stablekeepers Ordinance, O.N.W.T. 1884, No. 35, see now Livery Stable Keepers Act, R.S.A. 1980, c. L-20. Warehousemen's Lien Act, S.A. 1922, c.46, see now R.S.A. 1980, c. W-3. 
movement culminated in 1921 with the enactment of the Possessory Liens Act. ${ }^{16}$ This statute codified the artificer's lien by providing that a particular lien is available to a person who has expended money, labour or skill at the request of the owner and thereby enhanced the value of the goods. ${ }^{17}$ The Act provides a right of sale in favour of all liens within its scope. ${ }^{18}$ The statute also provides a lien in favour of a bailee to secure charges arising under a contract of bailment, thereby giving rise to a lien in favour of persons who provide services in relation to the goods but do not enhance their value. ${ }^{19}$

The final stage in the development of the statutory lien was the enactment of nonpossessory liens. These statutes relaxed the requirement that the lienholder retain possession of the property, but were typically available in cases where the lienholder had provided money or services in relation to the goods subject to the lien. The first of these liens were in favour of threshers in the agricultural sector ${ }^{20}$ and workers in the timber industry. ${ }^{21}$ Later statutes created a variety of non-possessory liens on crops in favour of municipalities, irrigation boards and other claimants. ${ }^{22}$ The lien on crops proliferated to such a degree that a statute was enacted in 1941 to settle the priority status of the various classes of lienholders who had liens on the same crop. ${ }^{23}$

In 1937, the province of Alberta became the first western province to enact garage keepers legislation that gave a repairer a non-possessory lien on a motor vehicle or farm vehicle. $^{24}$ The Garagemen's Lien Act is unlike the other non-possessory liens statutes in that it imposes a registration requirement on the lienholder in order to maintain the validity of the lien. The lienholder must register in the Personal Property Registry not later than 21 days after possession of the goods is surrendered to the owner. ${ }^{25}$

\section{B. RIGHTS OF DISTRESS}

Distress is the oldest form of self-help remedy available at common law. ${ }^{26}$ It permitted a person to take custody of goods away from another person in order to coerce performance of some duty. The common law right of distress today survives only in the

S.A. 1921, c. 10. See now Possessory Liens Act, R.S.A. 1980, c. P-13.

Ibid. s. 2.

Ibid. s. 10.

Ibid. s. 4.

Threshers' Lien Ordinance, O.N.W.T. 1895, No. 24. See now Threshers' Lien Act, R.S.A. 1980, c. T-4.

Woodmen's Lien Act, S.A. 1913(2), c. 28. See now Woodmen's Lien Act, R.S.A. 1980, c. W-14. Municipal Government Act, R.S.A. 1980, c. M-26, s.268 (lien on crops to secure commodity advances); Municipal Taxation Act, R.S.A. 1980, c. M-31, s.129 (lien on crops to secure taxes): Irrigation Act, R.S.A. 1980, c. 1-11, s. 151 (lien on crops to secure arrears); Hail and Crop Insurance Act, R.S.A. 1980, c. H-1, s. 18 (lien on crops for unpaid premiums). Crop Liens Priorities Act, S.A. 1941, c. 46. See now Crop Liens Priorities Act, R.S.A. 1980, c. C34.

24. Garagemen's Lien Act, S.A. 1937, c. 77. See now Garagemen's Lien Act, R.S.A. 1980, c. G-1.

25. Garagemen's Lien Act, R.S.A. 1980, c. G-1, s. 3, as am. S.A. 1988, c. P-4.05, s.83. 
form of the landlord's right of distress, ${ }^{27}$ and the exercise of this right has been substantially altered by legislation. ${ }^{28}$ The remedy can only be exercised in relation to goods located on the land in respect of which the rent is due, except that the landlord may distrain the goods from other premises within 30 days if there has been a fraudulent or clandestine removal of the goods from the premises. ${ }^{29}$ Certain classes of goods are exempt from distraint under common law $^{30}$ (the most significant category being goods held in custodia legis). Additional statutory exemptions are set out in the Exemptions Act. ${ }^{31}$ The right of distress at common law was available even against goods of a stranger found on the premises, but was later restricted by statute to the goods of the tenant. ${ }^{32}$ This restriction on the right of distress does not apply where the right was asserted against certain classes of third parties who claimed an interest in the goods (such as execution creditors and certain classes of secured creditors).

The first extra-judicial seizures statute was enacted in the midst of an economic recession (from 1913 to 1915) in response to calls for moritorium legislation. ${ }^{33}$ The legislation required that distress under leases and seizures under security agreements be undertaken by a sheriff or other person authorized by the sheriff and provided that a sale of the property could only be obtained upon the order of a Court. The requirement of an order of a Court for sale was eventually converted to a procedure under which an order for removal and sale was needed only if the debtor sent in an objection to the seizure. ${ }^{34}$

The right of distress was adopted at an early date as a remedy for the recovery of taxes, rates and other claims owing to government or quasi-governmental bodies. ${ }^{35}$ There is little consistency in the manner in which the law of distress is incorporated into these statutes. In some cases, a rudimentary right of distress is created and the provisions of the Seizures Act and Exemptions Act are made applicable to the exercise of the remedy. ${ }^{36}$ In other cases, the statute sets out different rules governing the scope and

27. Distraint damage feasant was available at common law and permitted a person to impound cattle until the owner had paid for damage that he had caused. It has been superseded by statute: see Stray Animals Act, R.S.A. 1980, c. S-23.

2x. Distress for Rent Act, 1689, 2 W \& M, c. 14 (landlord given right to sell the goods, remedies given for pound breach). Although the right of sale has been superseded by the procedure set out in the Seizures Act, R.S.A. 1980, c. S-11, the remedy for pound breach has been received into Alberta law: Westchester Equities v. Benwood Industries Lid. (1988), 57 Alta. L.R. (2d) 241 (Q.B.). Landlord and Tenant Act (Statute of $A m n$ ) , 1709, 8 Anne, c.18 (landlord given priority over exccution creditors for arrears of rent not exceeding one year). The statute has been received into Alberta law: Circa 1880 Imports Lid. v. Amtique Photo Parlour Lid. (1983), 27 Alta. L.R. (2d) 397 (Q.B.). Distress for Rent Act, 1737. Yule \& Co. (Hong Kong) Lud. v. Singh (1985), 71 A.R. 374 (M.C.) held that this Imperial statute has been received into Alberta.

Melton Real Estate Lid. v. National Arts Services Corp. Lid. (1977), 2 Alta. L.R. (2d) 180 (Dist. Ct.). R.S.A. 1980 , c. E-15, s.2.

Distress for Rent and Extrajudicial Seizure Act, C.O.N.W.T. 1898, c. 34, s. 4 (added by O.N.W.T. 1896, No. 7, s. 1). Sec now Seizures Act, R.S.A. 1980, c. S-11, s.19. The wording of the provision was amended on the coming into force of the PPSA by deleting the old terminology and adopting the terminology of the PPSA. See S.A. 1988, c. P-4.05, s.97.

Extra-Judicial Seizures Act, S.A. 1914, c.4.

Seizures Act, R.S.A. 1980 , c. S-11, ss. 26-30.

See, for example, North-West Municipal Ordinance, 1883, O.N.W.T. 1883, No. 2, s. 77.

Irrigation Act, R.S.A. 1980, c. I-11, s.150. 
exercise of the right of distress. ${ }^{37}$ The situation is further complicated by statutes which create a lien but provide for its enforcement through the exercise of a statutory right of distress. ${ }^{38}$

The right of distress is also available to a mortgagee who has included an attornment clause in its mortgage. The use of an attornment clause was not effective to create a real tenancy in the mortgagee under the Alberta land titles system. ${ }^{39}$ This was changed by statute $^{40}$ so that an attornment clause in a mortgage is deemed to create a real tenancy between the parties thereby giving the mortgagee a right of distress.

\section{STATUTORY CHARGES AND SECURITY INTERESTS}

There are two kinds of statutory devices in Alberta that are premised on the notion of a charge or security interest. The first is a form of consensual security interest in crops that secures commodity advances made by municipalities. ${ }^{H 1}$ The security interest comes into existence upon execution of a lien agreement. In place of registration under the PPSA, a crude form of public notification is provided through publication of notice in the Alberta Gazette. The enforcement of the lien agreement is through the same right of distress available to municipalities for the collection of unpaid taxes.

The second kind of device is a true non-consensual security interest which operates as a charge on all of the debtor's property. A good example of this device is the statutory charge created in favour of the Workers' Compensation Board. The legislation originally provided for a charge on all the property of the debtor. This was held to create a floating charge in favour of the Board which did not crystallize until a certificate of assessment was obtained or until distress proceedings had been initiated. ${ }^{42}$ The legislation was subsequently amended to provide that amounts due to the Board are secured by a "fixed, specific and continuing charge" on the employer's property and on any other property used by the employer in the industry. ${ }^{43}$ Realization on the charge is undertaken through the exercise of a statutory right of distress. ${ }^{44}$ A statutory charge is created to secure

37. Municipal Taxation Act, R.S.A. 1980, c. M-31, ss. 128, 133-135, 138, 141-42 (no requirement that a sheriff or person authorized by the sheriff conduct the seizure and different sale procedure); Drainage Districts Act, R.S.A. 1980, c. D-39, ss. 171-74 (distress made available in same manner as a landlord, but statute provides different rules in relation to the goods that may be seized and the sale procedure).

38. Hail and Crop Insurance Act, R.S.A. 1980, c. H-I, s.18(4); Special Areas Act, R.S.A. 1980, c. S-20, s.16(3).

39. Hyde v. Chapin Co. (1916), 26 D.L.R. 381 (Alta. S.C.).

40. Law of Property ACt, R.S.A. 1980, c. L-8, ss. 36 and 37. The right of distress is not as extensive as the landlord's right of distress since it is limited to the goods of the mortgagor and is subject to provincial exemptions. See Seizures Act, R.S.A. 1980, c. S-11, s. 20. Agricultural Relief Advances Act, R.S.A. 1980, c. A-10, ss. 12-16; Municipal Government Act, R.S.A. 1980, c. M-26, ss. 267-8.

42. Workmen's Compensation Board v. The Queen (1967), 61 D.L.R. (2d) 21 (Alia. S.C. A.D.).

43. Workers' Compensation Act, S.A. 1981, c. W-16, s. 126.

4. Workers' Compensation Act, S.A. 1981, c. W-16, s. 131. 
business taxes ${ }^{45}$ and public utilities, ${ }^{46}$ and a deemed security interest is created by the Employment Standards Code to secure the unpaid wages of employees. ${ }^{47}$

Amendments to the Income Tax Act, Canada Pension Plan and Unemployment Insurance Act contemplate the use of a statutory charge which is given priority over all other claims or security interests. ${ }^{48}$ The charge attaches after registration of a certificate of assessment in the Federal Court. The amendments have not been proclaimed into force and are unlikely to be implemented until such time as the Federal Court puts into place a national registry capable of processing a high volume of search requests.

\section{DEEMED STATUTORY TRUSTS}

Several statutes utilize the trust concept in order to create a non-consensual security interest in the debtor's property. Statutory trusts are often created in connection with legislation which requires a person to collect and remit a tax or premium. The pay-roll deductions of income tax, unemployment insurance and Canada Pension Plan premiums are the most common examples of such devices. ${ }^{49}$ The earlier deemed trust devices merely provided that the employer was deemed to hold the money collected in trust, but did not provide for the event that the money was not segregated and was not identifiable or traceable. The Supreme Court of Canada held that this device was not effective if the money was not traceable. ${ }^{50}$ As a consequence, this form of deemed statutory trust has fallen out of use. It has been superseded by statutory deemed trust provisions which provide that the employer is deemed to keep the money separate and apart whether or not it has actually been kept separate and apart. ${ }^{51}$

The deemed statutory trust was originally created in relation to source deduction and tax collection statutes which required a third party to collect and remit the money. More recently the deemed trust device has been extended to other kinds of claims. A deemed trust is imposed upon employers in respect of unpaid wages that have been earned by an employee. ${ }^{52}$ Employees are also given a deemed security interest to secure their claims for unpaid wages. This double-barrelled approach was adopted because at the time it was thought that a deemed trust, unlike a deemed security interest, would be effective in a bankruptcy of the debtor. This possibility has proven to be unfounded and as a result

45. Municipal Taxation Act, R.S.A. 1980, c. M-31, s. 125.

t6. Municipal Government Act, R.S.A. 1980, c. M-26, s. 309.

47. Employment Standards Code, S.A. 1988, c. E-10.2, s.113(2).

48. S.C. 1986, c.6, s. 118 (adding ss. 227(10.2) to (10.8) to the Income Tax Act), s. 132 (adding ss. 24(7) to (13) to the Canada Pension Plan) and s.135 (adding ss. 71(7) to (13) to the Unemployment Insurance Act). R.S.C 1985, c. C-8, s.23(3) and (4), as am. S.C. 1986, c. 6, s.132; Unemployment Insurance Act, R.S.C. 1985, c. U-1, s.57(2) and (3), as am. S.C 1986, c. 6, s.135.

52. Employment Standards Code, S.A. 1988, c. E-10.2, s.113(1). 
there is no advantage to be obtained in creating a deemed trust as a back-up to some other variety of non-consensual security interest. ${ }^{53}$

\section{E. STATUTORY DEMANDS}

A number of statutes create a statutory demand procedure under which a third party who owes an obligation to the debtor is given notice that the money is to be paid to the person making the demand. This kind of device is similar in operation to the garnishment procedure available to unsecured creditors, and has been available under income tax legislation almost from the time of its inception in $1917 .^{54}$ The original statutory mechanism did not give the claimant any proprietary interest in the debtor's property. ${ }^{55}$ The provision was amended in 1987 in an attempt to give the statutory demand priority over a prior secured party who had a security interest in the account. ${ }^{56}$ The provision was not well drafted and produced a division of opinion on whether it had the effect of giving the statutory demand priority, and the section was again amended in 1990 in order to achieve this result. ${ }^{57}$

\section{F. STATUTORY JUDGMENTS AND STATUTORY PREFERENCES}

Some statutes provide that a certificate of non-payment or other document may be filed with the clerk of the court and enforced in the same manner as a judgment. ${ }^{58}$ This confers a procedural advantage that eliminates the need to obtain a judgment of the Court. The procedure does not create a non-consensual security interest because the claimant is simply afforded the judgment enforcement measures available to an unsecured creditor. A statute may provide that a claim is preferred over other claims. In the absence of other provisions which create a non-consensual security interest in the property, this provision will only operate to give the claim preference over unsecured creditors. ${ }^{59}$ These types of provisions do not give the claimant any interest in the debtor's property. We therefore do not classify them as non-consensual security interests.

53. See the discussion, infra, at notes 226-228.

s. The Income War Tax Act was enacted in 1917 and the statutory demand provision was added in 1923: S.C. 1917 , c. 28 , am. S.C. 1923 , c. 52 , s. 10.

55. Royal Bank of Canada v. A.-G. Canada (1978), 105 D.L.R. (3d) 648 (Alta. S.C.A.D.); Re Zurich Insurance Co. \& Troy Woodworking Ltd. (1984), 6 D.L.R. (4th) 552 (Ont. C.A.).

37. See discussion, infra, at notes 214-218.

58. Public Utilities Board Act, R.S.A. 1980, c. P-37, s. 58; Workers' Compensation Act, R.S.A. 1980. c. W-16, s. 124.

59. A.G.-Alta. v. Board of Industrial Relations, [1976] 1 W.W.R. 756 (Alta. S.C.). 


\section{APPLICATION OF THE PPSA}

The PPSA only applies to security interests that arise out of a security agreement between the parties. ${ }^{60}$ Non-consensual security interests are not governed by the PPSA because they do not arise by virtue of an agreement between the parties, but are given to a claimant through operation of law. The intention to exclude non-consensual security interests is further manifested in the express exclusion from the scope of the Act of a "lien, charge or other interest given by an Act or rule of law in force in Alberta."

This is not to say that the provisions of the PPSA are irrelevant to the determination of a priority competition between a security interest governed by the PPSA and a nonconsensual security interest. The provisions of the PPSA will continue to be relevant in demarcating the enforceability, nature and extent of a consensual security interest. A nonpossessory security interest is not enforceable against a third party unless there is a written security agreement signed by the debtor containing an appropriate description of the collateral. ${ }^{62} \mathrm{~A}$ security interest is therefore invalid against a non-consensual security interest if this requirement is not met. Furthermore, the provisions governing time of attachment of the security interest may be relevant in cases where priority is determined by the order of creation of the competing interests. ${ }^{63}$ Finally, the PPSA contains a priority rule which subordinates a security interest to certain liens ${ }^{64}$ and this provision is sufficient to resolve some priority competitions without having to look to any other source. The point is simply that a non-consensual security interest is not a security interest within the meaning of the PPSA, and the priority rules of the Act which govern disputes between competing security interests do not apply.

The characterization of a device as a non-consensual security interest is simple in most cases. If the interest is created by statute or through the operation of the common law, it is properly regarded as a non-consensual security interest which falls outside the scope

PPSA, ss. 1(1)(pp), 1(1)(qq), 3. Canadian Life Assurance Co. v. Kupka (1991), I P.P.S.A.C. (2d) 258 (Alta. M.C.) (right of distress is not a security interest within the meaning of the PPSA). See also Canadian Imperial Bank of Commerce v. 64576 Man. Ltd., [1990] 5 W.W.R. 419 (Man. Q.B.), aff'd on other grounds [1991] 2 W.W.R. 323 (Man. C.A.).

PPSA, s. 4(a). This provision is wider than its counterpart in the Saskatchewan PPSA which refers to a "lien, charge or other interest given by statute or a lien given by rule of law for the furnishing of goods, services or materials" and the Manitoba and Ontario PPSA which expressly excludes only a lien given by statute or rule of law. Courts in these jurisdictions have strained the wording of these provisions in order to bring certain non-consensual security interests within the exclusionary language. See Re Dube and Bank of Montreal (1986), 27 D.L.R. (4th) 718 (Sask. C.A.) (right of distress regarded as a statutory interest rather than a common law interest in order to bring it within the exclusion in the Saskatchewan PPSA); Commercial Credit Corp. Lid. v. Henry D. Shields Ltd. (1981), 122 D.L.R. (3d) 736 (Ont. C.A.); Household Trust Co. v. Leslie Gowers Hotels Lid., [1991] 5 W.W.R. 228 (Man. C.A.) (right of distress considered a lien); Roynat Inc. v. Ja-Sha Trucking \& Leasing Lid., [1992] 1 W.W.R. (Man. Q.B.) (deemed statutory trust considered a lien), aff'd on other grounds [1992] 2 W.W.R. 641 (Man. C.A.). A better response is simply to exclude these interests from the scope of the Act because they are not security interests which arise out of a security agreement between the parties.

62. PPSA, s. 10(1).

63. PPSA, s. 12. And see the discussion, infra, at notes 165-171.

o. PPSA, s. 32. And see the discussion, infra, at notes 123-143. 
of the Act. If the interest arises out of a contract between the parties, the PPSA will apply to it. A central feature of the scope provisions of the Act is the focus upon the substance of the transaction. ${ }^{65}$ The parties to a security agreement cannot evade the application of the Act merely by referring to the security agreement as a lien. Lien notes and other similar security agreements are therefore brought within the scope of the Act.

Under the common law, a true possessory lien could be created by contract. Although the Act excludes from its scope a lien, charge or other interest given by an Act or rule of law, this exclusion does not apply to a contractual lien because it is derived from an agreement between the parties. ${ }^{66}$ A distinction should therefore be drawn between liens conferred by operation of law (such as artificers' liens and statutory liens), and liens created by agreement. Only the latter create security interests that are governed by the PPSA.

The status of general liens is more troublesome. The Ontario Supreme Court has held that the general lien of a stockbroker is a common law lien which is outside the scope of the Ontario PPSA. ${ }^{67}$ An examination of the common law position reveals that this conclusion is not well founded. General liens do not arise out of operation of law in the same manner as the particular liens recognized by the common law. A general lien arises by virtue of a usage of trade which is so accepted in the trade that every person is taken to know of its existence. ${ }^{68}$ A usage of trade is incorporated into the contract as an implied term. It would follow that because a common law general lien is a creature of contract ${ }^{69}$ it is governed by the PPSA. A general lien which arises by statute will not be governed by the PPSA, as it is created by operation of law. An attempt to create a general lien by express contract should similarly be regarded as a security interest governed by the PPSA.

The recognition of common law general liens as security interests within the scope of the PPSA would not disrupt current practices to any significant degree. The security interest could be perfected by possession ${ }^{70}$ (so that no registration would be required), in which case it would be enforceable against third parties even in the absence of a

Section 3(1)(a) of the PPSA provides that the Act applies to "every transaction that in substance creates a security interest, without regard to its form and without regard to the person who has title to the collateral."

to. Re John Deere Lid. and Clarkson Gordon Inc. (1986), 45 D.L.R. (4th) 641 (Man. C.A.). In Friend v. Bitter (1979), 1 P.P.S.A.C. 326 (Ont. Co. Ct.) it was held that the deposit of tille deeds to a vessel with the intention of securing a loan created an equitable lien. The use of this terminology by the Court is unfortunate since it may suggest that the PPSA does not apply to such a transaction (the question of the applicability of the PPSA was not argued in the case). The preferred approach would have been to recognize the transaction as a security interest governed by the PPSA. Jones v. Davidson Partners Ltd. (1981), I P.P.S.A.C. 242 (Ont. S.C.).

Brandao v. Barnett, supra, note 13, per Campbell.

A.P. Bell, Modern Law of Personal Property in England and Ireland (London: Butterworths, 1989) at 142; G.W. Patton, Bailment in the Common Law (London: Stevens \& Sons, 1952) at 345-346. PPSA, s. 24. In the case of stockbrokers, this would require that the broker obtain possession of the security certificate, which may not always occur. However, possession is required in order to assent a lien and therefore a stockbroker would be in no worse position by virtue of the application of the PPSA. 
written security agreement. ${ }^{71}$ The secured party could release the collateral for certain purposes and take advantage of a temporary perfection period. ${ }^{72}$ In most cases, ${ }^{73}$ Part 5 of the PPSA would govern the realization of the collateral in the event of a default. In the case of a general lien of a stockbroker, the secured party would not be required to give the debtor notice of the intended sale if they were sold on the market. ${ }^{74}$

A landlord's right of distress is not governed by the PPSA because it arises out of operation of law. ${ }^{75}$ A lease agreement may provide for a contractual right of distress which is created in order to secure obligations other than rent or to provide for distraint in locations other than the rented premises. A contractual right of distress will fall within the scope of the PPSA only if it creates an interest in the debtor's property. There is judicial authority to the effect that a contractual right of distress creates merely a contractual license to seize the debtor's goods. ${ }^{76}$ A contractual license is enforceable as between the parties but is not effective as against a third party claiming a competing interest in the goods because it does not create an interest in the debtor's property. As a result, the contractual right of distress would not be governed by the PPSA unless there were something in the contract to indicate that an interest was taken in the debtor's property. An attornment clause in a real property mortgage creates a true right of distress. This right of distress is excluded from the PPSA on the basis that it arises by operation of law since the interest is conferred by statute. ${ }^{77}$

\section{PARAMETERS OF THE NON-CONSENSUAL SECURITY INTEREST}

Once it is determined that a priority competition exists between a security interest governed by the PPSA and a non-consensual security interest, it becomes necessary to establish the legal parameters of the non-consensual security interest. We use the term legal parameters to denote the important characteristics of the non-consensual security interest that define the nature and extent of the interest. It is difficult to generalize on the nature and scope of non-consensual security interests because these matters are not governed by a single, unified source of law. The rules governing a right of distress differ substantially from the rules governing liens. There may also be little consistency when dealing with the same kind of device: the statutory rules governing one statutory lien may differ significantly from the rules governing another statutory lien. Despite this great diversity, there are several functional criteria that can be used in analysing the various non-consensual security interests. It is not our intention to provide an exhaustive analysis of the particular rules governing each device. Instead we simply offer the following criteria as a useful heuristic which we hope will assist the analysis.

\footnotetext{
71. PPSA, s. 10(1)(a).

72. PPSA, s. 26.

73. Part 5 would not apply to the solicitor's retaining lien which would be viewed as being subject to an implied agreement that the client's file would not be sold. Section 56(2) of the PPSA permits such contractual waiver by the secured party.

7.. PPSA, s. 60(15)(d).

75. See, supra, note 61 .

76. Trust \& Loan Co. of Canada v. Lawrason (1882), 10 S.C.R. 679; First National Bank v. Cudmore (1917), 34 D.L.R. 201 (Sask. S.C.); Hyde v. Chapin Co., supra, note 39.

77. Law' of Property Act, R.S.A. 1980, c. L-8, ss. 36 and 37.
} 


\section{A. SUBJECT MATTER OF THE NON-CONSENSUAL SECURITY INTEREST}

The first step in the analysis is to determine the property that is subject to the nonconsensual security interest. In the case of possessory liens, the lien is confined to property in the possession of the creditor. In the case of statutory liens and charges, the statute creating the lien will describe the property to which the non-consensual security interest attaches. For example, a garagemen's lien is limited to a motor vehicle or farm vehicle as defined in the statute. ${ }^{78}$ In some cases the non-consensual security interest is not limited to property owned by the debtor. For example, the statutory charge of the Workers' Compensation Board attaches to all property of the debtor and also to all property that is used by the debtor in the industry. ${ }^{79}$ A warehouseman's lien attaches both to goods deposited for storage by the owner and also to goods deposited by any person entrusted with possession of the goods by the owner. ${ }^{80}$

Where the non-consensual security interest takes the form of a non-possessory device, issues may arise about the identification of the property subject to a non-consensual security interest and the right to proceeds on disposition of the property. A loss of identity of the property subject to the non-consensual security interest will usually result in a loss of the interest. ${ }^{81}$ This may be modified by statute. For example, the Woodmen's Lien Act provides that a lien on logs or timber extends to any other logs that belong to the same owner which have been mixed with the logs or timber subject to the lien. ${ }^{82}$ The Supreme Court of Canada has held that a statutory lien does not give rise to a right to the proceeds of disposition unless the statute specifically provides that the lien extends to such property. ${ }^{83}$ A statutory right to proceeds is given by the Thresher's Lien Act which provides that the lien is lost upon sale to a bona fide purchaser, but becomes a first charge on so much of the price that remains unpaid when notice of the lien is given to the purchaser. ${ }^{84}$

The right of distress of the landlord is constrained in that it is generally available only in respect of the property located in the leased premises and is not available if the goods are in the custody of the law (in custodia legis). ${ }^{85}$ Although an attornment clause in a real property mortgage creates a real tenancy between the parties, the mortgagee's right to distrain against goods of third parties is limited by statute to the goods or chattels of the mortgagor (and not to property of third parties located on the premises) and is further restricted to goods that are not exempt under a writ of execution. ${ }^{86}$

\footnotetext{
78. Garagemen's Lien Act, R.S.A. 1980, c. G-1, ss. I(a) and (c).

79. Workers' Compensation Act, R.S.A. 1980, c. W-16, s. 126(1)(c).

so. Warehousemen's Lien Act, R.S.A. 1980, c. W-3, s. 3.

si. Pelly v. Ala, [1940] 1 W.W.R. 528 (Sask. C.A.).

k2. R.S.A. 1980 , c. W-14, s.5(2)(b).

83. Workmen's Compensation Board v. Bank of Montreal, |1968| S.C.R. 187.

R. R.S.A. 1980 , c. T-4, s. 2(3).

ss. See the discussion, infra, notes 181-186.

86.

Seizures Act, R.S.A. 1980, c. S-11, s. 20.
} 


\section{B. OBLIGATION SECURED}

A non-consensual security interest in many cases will not secure all obligations between the creditor and the debtor, but will be limited to a particular claim. Common law particular liens are restricted to the claim for labour or other services connected with the goods retained. A repairer's lien is lost upon the return of the goods to the owner. A return of those goods to the repairer for further repairs creates a lien that secures only the obligation associated with the work performed after re-acquisition of possession by the repairer. ${ }^{87}$ At common law the lien did not secure the costs of storage of the goods or the costs of enforcing the lien. ${ }^{88}$ This was changed by legislation which provided that the proceeds of sale of the goods should first be applied towards the costs of sale. ${ }^{89}$ Costs of storage are not generally recoverable unless the contract provides for the payment of storage charges. ${ }^{90}$

In the case of a landlord's right of distress, the obligation secured is limited to arrears of rent and is not available in respect of other obligations owed to the landlord. In the case of non-consensual security interests created by statute, the legislation must be consulted in order to identify precisely which obligations are secured by the nonconsensual security interest. For example, the Thresher's Lien Act confers a lien only for the cutting and threshing of grain and not for charges for hauling the grain to market. ${ }^{91}$ The Woodmen's Lien Act does not give a lien for charges for building roads unless incidental to the transportation of the logs from the bush. ${ }^{92}$ A lien under the Warehousemen's Lien Act not only secures charges for storage and preservation of the goods, but also secures charges for money advanced, insurance, transportation, labour, weighing and other expenses in relation to the goods. ${ }^{93}$ However, the legislation does not create a general lien that secures charges on goods that are no longer in the possession of the warehouse keeper. ${ }^{94}$ It is important to determine which obligations are secured by a lien because a valid lien may be lost if a lien claimant combines the claim with some other claim for which no lien is given. ${ }^{95}$

\section{FORMAL REQUIREMENTS}

Most non-consensual security interests are not subject to formal requirements such as a requirement that the contract be set out in writing. This is particularly true in the case of statutory interests in favour of government. However, some of the statutes that create

Royal Bank of Canada v. P.A. Aviation Services Ltd., [1987] I W.W.R. 234 (Sask. Q.B.). Somes v. British Empire Shipping Co. Ltd. (1860), 30 L.J. Q.B. 229; Canada Steel \& Wire Co. v. Ferguson Bros. (1915), 8 W.W.R. 416 (Man. C.A.).

Possessory Liens Act, R.S.A. 1980, c. P-13, s. 12.

Possessory Liens Act, R.S.A. 1980, c. P-13, s.9.

Barker v. Buck, [1934] I W.W.R. 223 (Man. C.A.).

Petersen v. Swan River Logging Co. Lid. (1961), 35 W.W.R. 254 (Alta. S.C.).

R.S.A. 1980 , c. W-3, s. 4.

Squamish Terminals Lid. v. Price-Waterhouse Lid. (1980), 26 B.C.L.R. 22 (S.C.). The United States counterpart to this legislation created a general lien in favour of the warehouse keeper. See Uniform Warehouse Receipts Act, s.28, 3 U.L.A. 144-5, superseded by U.C.C. 7-209.

Barker v. Buck, supra, note 91; Albemarle Supply Co. Lid. v. Hind \& Co., supra, note 5. 
non-consensual security interests in favour of non-public bodies impose a formal requirement essential to the validity of the non-consensual security interest. In particular, a garage keeper is required to get a signed acknowledgment of indebtedness as a condition of entitlement to the lien. ${ }^{96}$ A stable keeper's lien is not available unless a copy of the Act is posted in the premises. ${ }^{97}$

\section{TIME OF ATTACHMENT}

It may be necessary to review a statute to determine when a non-consensual security interest attaches (i.e., when the interest comes into existence). ${ }^{98}$ In the absence of a legislative priority rule or a common law principle that gives priority to a non-consensual security interest, the outcome of a priority competition often depends upon the order of attachment of the competing interests. ${ }^{99}$ In many cases the statute provides that the nonconsensual security interest attaches as soon as the obligation to pay arises. ${ }^{100}$ The federal deemed statutory trusts in respect of income tax, unemployment insurance and the Canada Pension Plan provide for a delay in attachment in that they do not arise until there is a liquidation, assignment, receivership or bankruptcy. ${ }^{101}$ If the secured party enforces its security interest by seizure and sale of the collateral rather than through the appointment of a receiver, the deemed trust does not come into existence and a priority competition never arises. ${ }^{102}$

Some statutes have been construed to create a floating charge which does not crystallize until a certificate of indebtedness is obtained or enforcement proceedings by way of distress are initiated. ${ }^{103}$ This approach is artificial. The statutes which create the liens or charges appear to contemplate that the interest comes into existence as soon as the obligation arises. The statutes contain no language to the effect that the interest

Garagemen's Lien Act, R.S.A. 1980, c. G-I, s. 2(3). The statute does not clearly specily the point in time when this requirement must be satisfied.

97. Livery Stable Keepers Act, R.S.A. 1980, c. L-20, s. 7. The legislation does not make it clear when this requirement must be satisfied (i.e. when the contract was entered into or when the lien is asserted).

See A.E. Hardy, Crown Priority in Insolvency (Toronto: Carswell, 1986) at 61-72 and 115-24.

See the discussion, infra, at notes 165-171.

For example. the deemed statutory trust under the Employment Standards Act, S.A. 1988. c. E-10.2, s. 113 comes into existence as soon as the obligation to pay is due or accruing due.

Income Tax Act, R.S.C. 1952. c. 148, s.227(5) as am. S.C. 1986, c.6. s.118(1); Canada Pension Plan Act, R.S.C 1985, c. C-8, s. 23(3) and (4): Unemployment Insurance Act, R.S.C. 1985, c. U-I, s. 57(2) and (3).

See Linder v. Rutland Moving and Storage Ltd., [1991] 4 W.W.R. 355 (B.C.C.A.) ("liquidation" and "receivership" refers only to the disposal of all the assets).

Workmen's Compensation Board v. The Queen, supra, note 42 (considering Workmen's Compensation Act, R.S.A. 1955. c. 370, replaced by Workers Compensation Act, S.A. 1981, c. W16. s. 126 which expressly provides that the charge is a fixed charge): Alberta Treasury Branches v. Invicuus Financial Corp. Lud. (1985), 55 C.B.R. (N.S.) 176 (Alta. Q.B.) (statutory charge securing utilities is a floating charge). But sce Alberta Treasury Branch v. Imvictus Financial Corp. Lud. (1986), 61 C.B.R. (N.S.) 238 (Alta. Q.B.); Re Bates Electric Ltd. (1972), 17 C.B.R. (N.S.) 253 (Alta. S.C.) (statutory charge securing business taxes likely does not create a floating charge); $R e$ Moumtstephen Construction Ltd. (1977). 25 C.B.R. (N.S.) 228 (Alta. S.C.) (statutory charge securing utilities is not a floating charge). 
floats or that attachment is otherwise delayed until enforcement proceedings are started.

\section{E. PERFECTION REQUIREMENTS}

The term "perfection" is borrowed from PPSA terminology to denote some further step that is required in order to protect the non-consensual security interest. The requirement is imposed in order to provide a means of discovering the existence of the interest and thereby ameliorate the age-old problem of the "secret lien." The two major perfection steps under the PPSA are registration and possession of the collateral by the secured party. As a general observation, non-consensual security interests conferred upon nonpublic bodies are typically subject to some form of perfection requirement; those conferred upon public bodies usually are not. ${ }^{104}$

Under the PPSA, an unperfected security interest is not void. It is enforceable as between the secured party and the debtor, but will be subordinate against most third parties who assert a competing interest in the collateral. The perfection requirements that are associated with non-consensual security interests differ from the perfection requirements under the PPSA. A failure to satisfy the perfection requirement usually has the effect of invalidating the non-consensual security interest in relation to both the debtor and third parties. An exception to this can be found in the Warehousemen's Lien Act ${ }^{105}$ which provides that a registered secured party must be notified of the lien within two months of the date of the deposit if the secured party did not authorize the warehousing of the goods. If the notice is not given, the lien is void as against the secured party for charges incurred after the two month period.

In the case of possessory liens, the creditor must retain possession of the goods. A loss of possession destroys the lien and a subsequent re-acquisition of possession does not result in a revival of it. Unlike the perfection by possession requirement of the PPSA, the lien claimant may retain possession even though the goods are returned to the debtor if the debtor agrees to hold the goods merely as bailee of the creditor. ${ }^{106}$ of course, this practice seriously degrades the usefulness of possession as a means of notifying third parties of the existence of the non-consensual security interest. In Saskatchewan it has been held that the enactment of non-possessory liens in favour of garage keepers replaced the right of such persons to maintain a lien through a bailment agreement. ${ }^{107}$

10.4. Sec, for example, Garagemen's Lien Act, R.S.A. 1980, c. G-1 (perfection by registration); Possessory Liens Act, R.S.A. 1980, c. P-13 (perfection by possession); Municipal Taxation Act, R.S.A. 1980, c. M-31 (no perfection required). However, if the proposed amendments to the Bankruptcy Act come into effect, registration may become more common for non-consensual security interests conferred upon the Crown. See discussion, infra, at notes 240-247.

111. R.S.A. 1980, c. W-3, s. 5.

116. Algoma Truck and Tractor Sales Lid. v. Blais (1981), I P.P.S.A.C. 319 (Ont. Dist. Ct.); Debor Contracting Lid. v. Core Rentals Ltd. (1982), 44 C.B.R. (N.S.) 9 (Ont. S.C.). And see, supra, note 5.

117. Canadian Commercial Bank v. Tisdale Farm Equipment Lid., [1984] 6 W.W.R. 122 (Sask. Q.B.), aff'd [1987] 1 W.W.R. 574 (Sask. C.A.). 
A true registration requirement is imposed only in the case of the garagemen's lien. A financing statement in respect of the lien must be registered in the Personal Property Registry within 21 days after possession of the vehicle is surrendered to the owner. ${ }^{108}$ The failure to register within this period results in a loss of the lien. The Woodmen's Lien Act creates a crude notification requirement. The lien does not remain a charge on the timber or lumber unless a statement of claim is filed with the clerk of the Court of Queen's Bench within certain time periods. ${ }^{109}$

\section{F. TERMINATION OF THE NON-CONSENSUAL SECURITY INTEREST}

Some statutes provide that the non-consensual security interest persists only for a limited period of time. The garagemen's lien continues for six months following the date of registration. The seizure of the vehicle must be initiated within this period unless the lien is extended by court order. ${ }^{110}$ The thresher's lien is available only from the date of commencement of the threshing until sixty days after its completion." ${ }^{\prime \prime}$ Legal proceedings to enforce a woodmen's lien must be taken within 30 days of filing a claim or the expiry of the period of credit. ${ }^{112}$ The landlord's right of distress must be exercised within six months of the termination of the tenancy, ${ }^{113}$ and is lost if the landlord elects to terminate the lease for breach of condition. ${ }^{114}$

\section{OVERLAP BETWEEN CONSENSUAL AND NON-CONSENSUAL SECURITY INTERESTS}

A creditor entitled to a non-consensual security interest may subsequently enter into a security agreement with the debtor. The consensual security interest may be taken in the same property as the non-consensual security interest, or it may be taken in different property. The question that arises is whether the taking of the security interest operates as a waiver of the non-consensual security interest, or whether the two interests exist concurrently. The controversy is most likely to arise in the case of a possessory lien, since the possession of the property by the creditor is consistent with an intention to create a possessory security interest governed by the PPSA. The mere fact that a security interest is taken in some other property to secure the obligation does not in itself amount to a waiver of the lien, unless there is something in the agreement which is inconsistent with the existence or continuation of the lien. ${ }^{115}$ However, if the security interest is

\footnotetext{
108. Garagemen's Lien Act, R.S.A. 1980, c. G-1, s. 2(3).

109. Woodmen's Lien Act, R.S.A. 1980, c. W-14, ss. 7-9.

110. Garagemen's Lien Act. R.S.A. 1980, c. G-1, s. 7.

III. Thresher's Lien Act, R.S.A. 1980, c. T-4. s. 1.

112. Woodmen's Lien Act, R.S.A. 1980, c. W-14, s. 10.

113. Manufacturers Life Insurance Co. v. Bullwinkle's General Stores Lid. (1983), 26 Alta. L.R. (2d) 279 (M.C.).

I14. Hallbauer v. Shipowick (1985), 38 Alta. L.R. (2d) 351 (M.C.).

is. Angus v. McLachlan (1883), 23 Ch.D. 330; Bank of Africa Ltd. v. Salisbury Gold Mining Co. Ltd., [1892] A.C. 281 (P.C.).
} 
taken in the same property as the lien, the creation of the security interest is more likely to be viewed as replacing the lien. ${ }^{16}$

The significance of waiver is illustrated in the following example. Suppose that a watchmaker retains possession of a watch which has been repaired. The parties agree that the watch will not be returned to the owner until payment of the bill for the repairs together with payment of some additional obligation. If the transaction is held to operate as a waiver of the possessory lien, the watchmaker will have a consensual security interest in the watch in place of the lien. The security interest will be governed by the PPSA. The proper notice and sale procedure is that set out in Part 5 of the PPSA, and not that set out in the Possessory Liens Act. The perfection requirements that must be satisfied are those of the PPSA, and not those pertaining to possessory liens. The surrender of the goods to the debtor under a bailment agreement would therefore be insufficient to maintain the perfected status of the security interest. ${ }^{117}$ Furthermore, the security interest would not enjoy the special PPSA priority rule conferred upon artisan's liens in section 32 of the PPSA.

There are other significant differences between the law governing consensual security interests and that governing possessory liens. A security interest may be assigned to a third party, ${ }^{118}$ whereas a lien is a personal right which cannot be assigned. ${ }^{119}$ Loss of perfection will not result in the destruction of a security interest (as is the case with a lien), but will merely render it subordinate to third parties. ${ }^{120}$

\section{RESOLUTION OF PRIORITY COMPETITIONS BETWEEN PPSA SECURITY INTERESTS AND NON-CONSENSUAL SECURITY INTERESTS}

\section{A. OVERVIEW}

Priority competitions will frequently arise between non-consensual security interests and security interests governed by the PPSA. The PPSA contains an exhaustive set of priority rules for competitions between security interests within the scope of the Act. ${ }^{121}$ However, a non-consensual security interest is not a security interest for the purpose of the PPSA, and therefore these rules are not applicable. The PPSA also contains priority rules which govern competitions between security interests and other interests which do not fall within the scope of the PPSA. For example, the PPSA contains an extensive set

116. In re Leith's Estate (1866), 1 L.R. P.C. 266; Morrison v. Bryan, supra, note 9; In re Morris, [1908] 1 K.B. 473 (C.A.).

117. PPSA, s. 24(2).

118. PPSA, s. 41.

119. Adanac Tire and Retreaders Lid. v. Sheriff of Judicial District of Edmonton (1979), 9 Alta. L.R. (2d) 66 (Dist. Ct.).

120. PPSA, s. 20.

121. A priority competition between two security interests may be determined by a special priority rule (such as the purchase-money security interest priority in section 34). In the absence of a special priority rule, the competition will be determined by the general priority rule of section 35 . 
of rules governing competitions between security interests and buyers. ${ }^{122}$ In the case of priority competitions between security interests and non-consensual security interests, the PPSA is much less comprehensive. Section 32 of the PPSA sets out a single priority rule which applies only to a certain class of liens. Clearly some other source of principles for resolving priorities must be found for non-consensual security interests which do not fall within this provision.

We propose to set up an analytical framework that can be used to resolve these often difficult problems of priority. This framework can be summarized as follows:

(1) Determine if the PPSA provides a rule for resolving the priority competition. The primary issue is whether or not the non-consensual security interest falls within section 32 of the PPSA. If it does, the non-consensual security interest is entitled to priority over the PPSA security interest, unless a provision in the Act creating the lien provides otherwise.

(2) If section 32 does not apply, determine if a non-PPSA legislative or common law priority rule confers priority upon the non-consensual security interest.

(3) In the absence of a non-PPSA legislative or common law priority rule, priority is determined according to the order of attachment of the competing security interests.

We will begin by giving a detailed account of the considerations that go into each of these three steps. We will then apply this approach to the categories of non-consensual security interests previously identified in Part II of this article.

\section{B. PRIORITY RULES CONTAINED IN THE PPSA}

\section{Section 32}

Section 32 of the PPSA provides as follows:

Where a person in the ordinary course of business furnishes materials or services with respect to goods that are subject to a security interest, any lien that he has with respect to the materials or services has priority over a perfected or unperfected security interest in the goods unless the lien is given by an Act that provides that the lien does not have priority.

The priority accorded a lien claimant under section 32 is dependant on four conditions. First, the priority is granted only to liens and not to other kinds of interests such as charges or deemed trusts. ${ }^{123}$ Some cases have held that a landlord's distress is a 
lien. ${ }^{124}$ Even if a landlord's distress is classified as a lien, section 32 would not apply because the landlord does not furnish materials or services with respect to the goods.

Second, the lien must be on goods. This excludes liens that are on personal property which do not meet the definition of goods, such as a lien on a corporation's shares, ${ }^{125}$ on an award of damages, ${ }^{126}$ or on proceeds from an insurance policy. ${ }^{127}$

A third requirement is that the lien claimant must supply materials or services. A number of liens are clearly excluded from the operation of section 32 as a result of this requirement. ${ }^{128}$ With other liens the issue is not as clear. In particular, does a storage lien involve the provision of services? ${ }^{129}$ Some guidance on this issue can be gained from reviewing the Official Comment to section 9-310 of the Uniform Commercial Code, on which section 32 was based. The purpose of the provision is described as follows: ${ }^{130}$

To provide that liens securing claims arising from work intended to enhance or preserve the value of the collateral take priority over an earlier security interest even though perfected.

In discussing this policy justification, Gilmore states that "it would be giving the holder of the security interest an unjustifiable windfall to allow him to claim the property, thus improved, while the serviceman remains unpaid." 131 In other words, the lien claimant favoured by section 32 is a person who has supplied materials or services that have increased or preserved the value of the collateral, over and above the value that might otherwise have been expected.

The common law required that the lien claimant expend money, labour or skill and thereby enhance the value of the goods. ${ }^{132}$ Liens were not available for storage or maintenance of goods because the requirement of enhancement in value was not

See, supra, note 61 . This strained interpretation no doubt was motivated by the desire to bring the right of distress within the express exclusion of liens from the scope of the Act. This artificial approach is unnecessary in Alberta because exclusionary language in section 4 of the PPSA extends to a "lien, charge or other interest given by an Act or rule of law."

125.

126.

127.

128

139. Warehousemen's Lien Act, R.S.A. 1980, c. W-3, s. 3; Possessory Liens Act, R.S.A. 1980, c. P-13, s.4. The issue is not of great significance in the case of a warehouseman's lien because the Warehousemen's Lien Act provides that the lien has priority over a prior security interest. The issue would be of significance in relation to other forms of storage liens which are governed by the Possessory Liens Act (e.g., repair and storage charges of a business primarily engaged in the repair of goods).

131. Uniform Commercial Code, Official Text, 9th ed. (Philadelphia: American Law Institute, 1978),

131. G. Gilmore, Security Interests in Personal Property, vol. 2 (Boston: Little, Brown and Co., 1965) at 878 .

132. This requirement has been codified in the Possessory Liens Act, R.S.A. 1980, c. P-13, s. 2. 
present. ${ }^{133}$ The same argument might be made in respect of section 32 . However, we are of the view that common law enhancement of value requirement should not be read into section 32. This requirement led to artificial and commercially unrealistic distinctions between work that enhanced value and work or storage which merely preserved value, and ultimately resulted in the passage of legislation which recognized liens for storage and maintenance of goods. Section 32 merely provides that the materials or services must be furnished in respect of the goods, and this requirement is satisfied in the case of a storage lien. This view is also taken in the United States where it has been held that a lien for storage is entitled to the benefit of the priority rule. ${ }^{134}$

A further question is whether the requirement that materials or services be furnished is satisfied where the contribution to the goods covered by the lien is indirect. For example, an irrigation lien on crops can cover capital asset charges on irrigated land. ${ }^{135}$ A woodmen's lien is available not only to those who work directly with the logs, but storekeepers and cooks as well. ${ }^{136}$ In principle, section 32 should apply to materials or services both directly and indirectly supplied to goods. In many cases it may be difficult to distinguish between direct and indirect application of materials or services. A directness test is not specified in the language of section 32, nor is it suggested by its policy justification. Instead, a two step approach should be used. First, one must determine whether there is any connection between the materials or services and the goods subject of the lien. Second, one must determine whether that contribution is associated with an enhancement or preservation of the goods.

The fourth requirement is that the materials or services must be furnished in the ordinary course of the lien claimant's business. Gilmore suggests that this requirement may be used to deny or reduce an inflated claim by a lienholder. ${ }^{137}$ To date this argument has not been raised in any reported Canadian decision. A more direct way of dealing with an inflated claim would be to examine the contractual relationship between the lienholder and the debtor, and determine whether the claim was justified under the contract. However, Gilmore's suggestion may be useful where there has been collusion between the lienholder and the debtor to produce an inflated claim to the detriment of a secured creditor.

The priority accorded to a lien that otherwise meets the requirements of section 32 can be lost if "the lien is given by an Act that provides that the lien does not have priority." Examples of statutory liens which fall within this proviso include the lien of a garage keeper and the lien of a thresher. The garage keeper's lien is subordinate to interests that

Supra, notes 8 and 9.

Security National Bank \& Trust Co. of Norman v. Reiginger (1980), 610 P. 2d 1222, 29 U.C.C. Rep. 1061 (Okla. S.C.). The case gives priority to a storage lien without expressly addressing the issue of whether storage is "materials or services." A leading American author on Article 9 of the UCC favours the view that storage liens should be covered by s. 32: B. Clark. The Law of Secured Transactions under the Uniform Commercial Code, 2nd. ed., (Boston: Warren, Gorham and Lamont. 1988) at 3-66 to 3-67. 
were created after the vehicle is surrendered to the debtor and before a financing statement protecting the lien is registered. ${ }^{138}$ The thresher's lien is subordinate to a person who takes possession of the grain and advances money on the security of it. ${ }^{139}$

At common law, a valid lien could not be created unless the owner of the goods or a person authorized by the owner requested that the work be done. ${ }^{140}$ This raised problems in the context of chattel mortgages and conditional sales agreements. The chattel mortgagee or the conditional vendor were viewed as being the owner of the goods. The debtor was generally viewed as having the express or implied authority to authorize the work. However, many security agreements contain clauses requiring the debtor to keep the collateral free from liens ("no-lien clauses"). The question prior to the passage of the PPSA was whether such a clause invalidated a lien claim. Some courts held that a no-lien clause was ineffective as against a repairer's claim to a lien on the ground that the authorization to repair could be derived from the debtor's covenant to keep the chattel in good repair. ${ }^{141}$ Other authorities took the view that a no-lien clause provided an express limitation on the authority of the debtor to create a lien, but that a repairer could rely upon the debtor's ostensible authority if the lien claimant did not know of the "nolien" clause. ${ }^{142}$ A repairer who had notice of a "no-lien" clause could not assert a lien against the secured party because the repairer knew of a limitation on the authority of the debtor.

This kind of analysis should no longer be applied now that the PPSA is in force. The PPSA has fundamentally altered the significance of title. The PPSA is not concerned with form and title. ${ }^{143}$ For the purposes of section 32 , the debtor should be regarded as the owner of goods that are subject to a legal interest (a security interest) which gives a

R.S.A. 1980, c. G-1, s. 5. A literal interpretation of s. 5 would give priority to any security interest, perfected or unperfected, arising before the registration of the financing statement protecting the lien. However, prior to the introduction of the PPSA, s. 5 was given a more restricted meaning, and interpreted as only referring to security interests that arise after the garagemen's lien comes into existence, but before it is registered: $R$. Angus Alberta Lid. v. Union Tractor Lid. (1967), 61 W.W.R. 603 (Alta. Dist. Ct.); Bank of Nova Scotia v. Henuset Resources (1987), 50 Alta. L.R. (2d) 253 (Alta. Q.B.). The rationale for this interpretation was that prior to the enactment of the Garagemen's Lien Act a garage keeper could secure repair costs only through the use of a possessory lien. If a possessory lien was claimed, it would take priority over another security interest. The garage keeper's lien was to facilitate the business of the debtor by allowing the debtor to obtain possession of the vehicle subject to the lien, while still maintaining a lien in favour of the garage keeper. It was not intended that the position of the garage keeper should be subordinated generally. This rationale continues to have validity in the PPSA era, and as such the restricted interpretation of s. 5 should continue to prevail.

139. Threshers' Lien Act, R.S.A. 1980, c. T-4, s. 2(4) (the lender must be bona fide and without knowledge of the existence of the lien).

140. This requirement was codified in the Possessory Liens Act, R.S.A. 1980, c. P-13, s. 2. It is not applicable in the case of liens of innkeepers and common carriers which may be asserted against owners who did request or authorize the services.

14. Commercial Finance Corp. v. Stratford (1920), 47 O.L.R. 392 (H.C.); Sterling Securities Corp. Lid. v. Hicks Motor Co., [1928] 2 W.W.R. 74 (Sask. C.A.).

142. Albemarle Supply Co. v. Hind \& Co., supra, note 5; Continemal Bank of Canada v. Henry Mogensen Transport Ltd. (1984), 32 Alta. L.R. 116 (M.C.).

143. Section 3(1)(a). 
secured party the right to proceed against the goods in the event of a default. As such, the debtor is fully capable of authorizing repairs to the goods. The agency analysis which formerly prevailed has been replaced by a legislative policy (contained in section 32) which favours lien claimants who enhance or preserve the value of collateral. A no-lien clause in a security agreement should be viewed as a covenant between the secured creditor and the debtor. A breach of this term may constitute an event of default if the agreement so provides, but it does not limit the priority conferred upon a lien claimant by section 32 .

\section{Section 20}

Section 20(1)(c) of the PPSA subordinates an unperfected security interest to a transferee for value who acquires an interest in personal property under a transaction that is not a security agreement. The transferee must acquire the interest for value and without knowledge of the security interest. If the secured party has failed to perfect its security interest, a holder of a non-consensual security interest may attempt to obtain the benefit of the subordination of the security interest under section $20(1)(c)$. The crucial point is whether the holder of a non-consensual security interest is considered to be a "transferee." There is no definition of transferee in the Act, and the term is certainly broad enough to include non-consensual security interests. ${ }^{144}$

There are two arguments that might be marshalled in favour of the application of section $20(1)(c)$ to non-consensual security interests. First, it might be argued that because the definition of "purchase"145 is restricted to consensual transactions, the use of the term "transferee" shows an intention to encompass non-consensual transfers as well. Second, it has been held that the recipient of an order for distribution of property under matrimonial property legislation is a transferee under section $20(1)(c)$, and this lends support to the view that the provision covers non-consensual transfers. ${ }^{146}$

We are of the view that these arguments are not persuasive and that the reference to transferees in section $20(1)$ (c) should not be interpreted to include non-consensual security interests. A contextual reading of section $20(1)$ (c) leaves no doubt that it was designed to subordinate an unperfected security interest to an interest created by a consensual transaction. The provision requires that the transferee give value. This clearly contemplates a transfer by way of a voluntary transaction, and it is quite artificial to say that a holder of a non-consensual security interest, such as a landlord who has a right of distress for arrears of rent, gives value for the goods seized. Furthermore, section 20(1)(c) provides that the interest of the transferee must be acquired out of a "transaction that is

See, for example. American Abell Engine and Thresher Co. v. McMillan (1909), 42 S.C.R. 377 (an instrument charging land is a transfer under the Dominion Lands $A c t)$. There are also other cases that interpret "transfer" more narrowly: see, for example, Langley v. Kalmert (1904), 7 O.L.R. 356. affirmed 9 O.L.R. 164 (consignment agreement did not amount to a transfer for the purposes of the Bills of Sale Act): Re Gill Lumber Chipman (1973) Lid. (1973), 42 D.L.R. (3d) 271 (N.B.S.C.) (transfer "means to make over the legal title or ownership").

146. Carr v. Shamrock Credit Union, [1984] 4 W.W.R. 688 (Sask. Q.B.). 
not a security agreement," and must be acquired without knowledge of the unperfected security interest at the time the interest is acquired. Again, this language is wholly inappropriate to non-consensual security interests which arise not by virtue of a transaction but by operation of law. The exclusion of non-consensual security interests from section 20(1)(c) is justified because non-consensual security interest claimants do not generally fall within the class of persons whose behaviour would be influenced by knowledge of the existence of a security interest. Non-consensual security interest claimants do not typically search the registry and therefore should not obtain the benefit of a subordination of the security interest for lack of perfection.

Section 20(1)(a) of the PPSA subordinates an unperfected security interest to the interest of a person who seizes "under legal process to enforce a judgment." This terminology contemplates seizures under the provincial judgment enforcement system. It excludes seizures pursuant to non-consensual security interests, such as a right of distress, because the seizure is not undertaken to enforce a judgment. ${ }^{147}$

\section{NON-PPSA LEGISLATIVE AND COMMON LAW PRIORITY RULES}

If section 32 of the PPSA does not apply, there may be legislative rules outside the PPSA or common law rules that give priority to the non-consensual security interest. The operation of non-PPSA legislative priority rules will be considered first, followed by a discussion of the more limited situations in which common law priority rules apply.

\section{Legislative Priority Rules}

In priority competitions between secured parties and non-consensual security interests, the security interest is usually the first to be created. There is a simple reason for this phenomena. Security interests are typically created when the debtor is in good financial health. Non-consensual security interests often come into existence when the debtor is in financial difficulties and failing to meet its obligations. In the absence of a legislative priority rule, priority will generally be obtained by the first in time and the secured creditor will usually emerge victorious. In an attempt to enhance the priority position of the non-consensual security interest, the governing statute will often include special language which purports to give the interest priority over prior security interests. Courts in interpreting these provisions have tended to apply a very strict reading which in many cases has rendered the statutory priority provision ineffective.

The leading statement of this principle is found in the Supreme Court of Canada decision in Board of Industrial Relations v. Avco Financial Services Realty Ltd. ${ }^{148}$ The Court held that legislation should not be interpreted in a manner so as to deprive secured creditors of their pre-existing property rights unless there is clear statutory language to this effect. The Alberta Court of Appeal has been particularly keen to uphold the property 
rights analysis. ${ }^{149}$ An analysis of these cases indicates that there are two kinds of legislative flaws that have attracted the Avco principle of interpretation.

The first category of flaw occurs if the statute fails to specify the property to which the non-consensual security interest attaches. The Avco case provides an example of this type of flaw. The legislation provided that the amount of unpaid wages "constitutes a lien and charge in favour of the Board payable in priority to any claim or right...and...such priority shall extend over every assignment of book debts, whether absolute or otherwise, every mortgage of real property, and every debenture." The legislation was said to be ambiguous because it did not make it clear whether the lien attached only to the debtor's property (i.e., the debtor's unencumbered interest in the property after the prior security interest had been satisfied) or if it attached to any property in which the debtor had an interest (i.e., property subject to a pre-existing security interest). Because the statute did not clearly specify the subject-matter of the lien, the ambiguity was resolved in favour of the secured party so as not to deprive it of its pre-existing property rights.

A second category of flaw involves a failure to clearly identify which parties are subordinate to the non-consensual security interest. There are a number of examples of this type of flaw. In one case, a priority provision that gave the non-consensual security interest priority over "all other claims" was found to be insufficiently clear to give the interest priority over a prior security interest. ${ }^{150}$ In other cases, a lien on the property of the employer for unpaid wages was held to be subordinate to a pre-existing security interest even though the statute gave the lien priority over any other claim or right, including a mortgage or debenture. ${ }^{151}$ The Alberta Court of Appeal ${ }^{152}$ has held that the priority language in the Prairie Grain Advance Payments Act ${ }^{153}$ is insufficient to give the Wheat Board priority. The statute creates a lien on grain, and provides that payment should be made to the board in priority over any other person. This language was held not to be sufficiently clear to deprive a secured party of pre-existing property rights. The creation of a "first lien" is also insufficient to give the lien priority over a prior security interest in the absence of language to the effect that the lien attaches to the interest of third parties. ${ }^{154}$

The identification of the subject matter of the lien (i.e., whether it attaches only to the debtor's unencumbered interest) and the specificity of the priority language are often related questions. If the priority language states that the non-consensual security interest

Lloyds Bank Canada v. International Warranty Co. (1989), 68 Alta. L.R. (2d) 356 (Alta. C.A.), leave to appeal to the Supreme Court of Canada refused (1989), 70 Alta. L.R. (2d) liii (statute must be plain and unambiguous before a court will deprive a secured creditor of its security without compensation); C.I.B.C. v. Klymchuk, [1990] 5 W.W.R. 214 (Alta. C.A.) (confiscatory nature of statute must be expressed in the clearest (erms).

Gatsby Enterprises (Kelowna) Lid. v. Gatshy Kelowna (1976) Ltd. (1978), 30 C.B.R. (N.S.) 1 (B.C.S.C.).

15. Re Federal Business Development Bank and Perron (1980), 113 D.L.R. (3d) 58 (Man. C.A.); Re Director of Employment Standards (1981), 123 D.L.R. (3d) 58 (Man. C.A.).

153. R.S.C. 1985, c. P-18, ss. 14-15.

154. Crown Trust Co. v. Workmen's Compensation Board (1955), 55 D.L.R. (3d) 498 (Ont. H.C.). 
should have priority over prior security interests, this is a clear indication that the interest attaches to more than the debtor's unencumbered interest and should be sufficient to give the claimant priority.

The principle espoused in Avco has a sound basis in policy. The legislation should express a priority rule in clear and unambiguous terms. However, in many cases it appears that the Courts have been excessive in their application of the Avco principle. ${ }^{155}$ These decisions appear to be motivated by a judicial distaste for legislation which deprives an existing secured party of its proprietary interest and a reluctance to give effect to it unless the wording of the statute is so clear that a refusal would compromise the legitimacy of the interpretive process. This has led to two counter-responses, one judicial and one legislative.

The judicial response in some jurisdictions has involved a less rigorous application of the Avco principle. From an early date, courts departed from a strict constructionist approach and applied a liberal interpretation in favour of statutory liens conferred upon threshers ${ }^{156}$ and woodworkers ${ }^{157}$ notwithstanding that these deprive existing security interests of their priority. More recently, Courts in Saskatchewan have demonstrated a willingness to uphold the underlying legislative intent and give non-consensual security interests in favour of public bodies priority over pre-existing security agreements. ${ }^{158}$ It is possible that this approach is associated with a perception that the expansion of secured credit in the 20th century has been at the expense of other creditors. ${ }^{159}$

The legislative response has sometimes resulted in a Darwinian adaptation of the statute in order to ensure survival (priority) of the non-consensual security interest. Each time a court finds a flaw in the legislation, it is replaced with a new and improved version. Eventually, the non-consensual security interest is drafted so tightly that it can survive even the closest judicial scrutiny. ${ }^{160}$ For example, the Workers' Compensation Act ${ }^{161}$ provides that the statutory charge is "a fixed, specific and continuing charge" (thereby avoiding the argument that attachment is delayed until crystallization of a charge) which attaches not only to the property of the employer but to any property used by the employer (thereby ensuring that it is not construed to attach only to the debtor's

155. Re Federal Business Development Bank and Perron, supra, note 151; C.I.B.C. v. Klymchuk, supra, note 149.

Ostevik v. Pioneer Grain Co. Ltd., [1932] 3 W.W.R. 148 (Sask. Dist. Ct.); Hill v. Strait (1913), 5 W.W.R. 225 (Man. K.B.) (liberal interpretation should be given to thresher's lien legislation).

157. Warehouse Security Finance Co. Ltd. v. Oscar Niemi Lid., [1944] 3 W.W.R. 567 (B.C.C.A.). Royal Bank of Canada v. 238842 Alberta Ltd., [1985] 5 W.W.R. 373 (Sask. C.A.) (preferential lien for water rates).

159. See R.M. Goode, "Is the Law Too Favourable to Secured Creditors?" (1983-84), 8 C.B.L.J. 53; J.S. Ziegel, "The Supreme Court of Canada Scuttles the Deemed Trust in Bankruptcy" (1989), 15 C.B.L.J. 498; M.G. Shanker, "The Worthier Creditors (and a Cheer for the King)" (1975-6), 1 C.B.L.J. 340. See the discussion of the statutory demand under s.224 of the Income Tax Act, infra, at notes 214218.

161. R.S.A. 1980 , c. W-16, s. 126(1). 
unencumbered interest). A further provision states that the charge is payable in priority over: ${ }^{162}$

...all writs, judgments, debts, liens, charges, security interests as defined in the Personal Property Security Act, rights of distress, assignments (including assignments of book debts) and other claims or encumbrances of whatever kind of any person, including the Crown, whether legal or equitable in nature, whether absolute or not, whether specific or floating, whether crystallized or otherwise perfected or not and whenever created or to be created.

\section{Common Law Priority Rules}

In two cases, the common law non-consensual security devices give the claimant a right to proceed against not only the property of the debtor, but also against the property of third parties. ${ }^{163}$ The lien of the innkeeper and the common carrier may be asserted against goods even though they may not belong to the debtor. ${ }^{164}$ This gives the liens priority against prior secured creditors who have security interests in the debtor's goods and third parties who have absolute ownership of the goods in the debtor's possession. The right of distress of the landlord could also be asserted against goods of third parties located on the leased premises, but this right has been substantially cut-down by legislation.

\section{ORDER OF ATTACHMENT}

In the absence of an effective legislative or common law priority rule that gives the non-consensual security interest priority over a prior security interest, a priority competition is determined according to the order of the time of attachment. ${ }^{165}$ As a consequence, a non-consensual security interest will be subordinate to a prior security interest, and will have priority over a subsequent security interest. Determining the time of attachment is therefore crucial under this residual priority rule. Time of attachment of a security interest under the PPSA is expressly governed by the PPSA which sets out the criteria which must be satisfied before attachment occurs. ${ }^{166}$ Time of attachment of a non-consensual security interest has been previously examined. ${ }^{167}$

Ibid. s. 126(2).

163. E.L.G. Tyler and N.E. Palmer, Crossley Vaines on Personal Property, 5th ed., (London: Butterworth's, 1973) at 142-143; Halshury's Law's of England, 4th ed., vol. 28, (London: Butterworth's, 1979) at 236.

164.

The priority rule in favour of innkeepers originates from the common law and is not available to boarding house keepers and lodging house keepers, who are entitled to a statutory lien (but not a common law lien) by virtue of the Innkeepers Act, R.S.A. 1980, c. I-4, s. 2. See Newcombe v. Anderson (1886), 11 O.R. 665.

165. Time of attachment is often not expressly invoked as the priority rule, but it underlies the decisions in the area and flows directly out of the Avco principle favouring pre-existing security interests. See also, Hardy, supra, note 98. PPSA, s. 12.

167. See the discussion, supra, at notes 98-103. 
Prior to the coming into force of the PPSA, the use of a floating charge had a significant effect on the issue of priorities. The security interest did not specifically attach to the debtor's assets until the floating charge crystallized. Crystallization in most cases was constituted by an act of intervention by the secured party (usually through the appointment of a receiver). A non-consensual security interest which attached prior to crystallization was entitled to priority even though the floating charge debenture might have been executed before the non-consensual security interest came into existence. ${ }^{168}$

The PPSA has fundamentally changed the characterization of security interests. Section 12 of the PPSA specifies when the security interest comes into existence, and this provision makes it clear that the old notion of crystallization is no longer of any relevance. Although modernized forms of security agreements (such as general security agreements) have rapidly replaced the use of the old forms of agreements, the parties may continue to use the older forms of agreements. However, the use of a floating charge debenture does not indicate that parties intend that the time of attachment should be delayed. $^{169}$ The case authority which subordinated the floating charge to precrystallization interests should be of no application or significance under the PPSA.

Unfortunately, traditional views of the floating charge still haunt some court decisions in the area. The Ontario Court of Appeal in Re Standard-Modern Technologies Corp. ${ }^{170}$ subordinated a prior floating charge to a statutory lien in favour of the Worker's Compensation Board on the ground that the floating charge did not crystallize until after the lien had come into existence. The effect of the PPSA on the floating charge was not considered on the theory that the Act did not apply because of the exclusion of liens from its scope.

Non-consensual security interests are clearly excluded from the operation of the PPSA. This means that the validity, attachment and enforcement of non-consensual security interests is not governed by the Act. However, the PPSA continues to govern the validity, attachment and enforcement of consensual security interests. The Act contains a comprehensive provision that sets out the pre-conditions for attachment, and this eliminates any need to resort to pre-PPSA concepts such as crystallization.

Dauphin Plains Credit Union Lid. v. Xyloid Industries Lud., supra, note 50; R. in Right of British Columbia v. Federal Business Development Bank, [1988] 1 W.W.R. 1 (B.C.C.A.). If the floating charge crystallized before the non-consensual security interest attached, the floating charge obtained priority: Re Caroma Enterprises Lid. (1979), 108 D.L.R. (3d) 412 (Alta. Q.B.). Lid. (1985), 16 D.L.R. (4th) 289 (Ont. C.A.). See also R.J. Wood, "The Floating Charge in Canada" (1989), 27 Alta. L. Rev. 191; R.C.C. Cuming, "Commercial Law - Floating Charges and Fixed Charges of After-Acquired Property: The Queen in Right of British Columbia v. Federal Business Development Bank" (1988), 67 Can. Bar Rev. 506, at 518-522; R.C.C. Cuming and R.J. Wood, Alberta Personal Property Security Act Handbook (Toronto: Carswell, 1990) at 87-88; J.S. Ziegel, "Recent Developments in the Personal Property Security Area" (1985), 10 C.B.L.J. 131. 
The decision of the Ontario Court of Appeal can only create confusion. It suggests that attachment is ascertained pursuant to the PPSA if the competition is with a secured party or a buyer, but according to pre-PPSA concepts, if the contest is with a lien. A more sensible approach was adopted by the Saskatchewan Court of Appeal in Royal Bank v. G.M.Homes Inc. ${ }^{171}$ The Court held that section 12 of the PPSA provides the rules for attachment and that the notion of crystallization is of no relevance. We are of the opinion that this approach is to be preferred.

\section{E. PRIORITY STATUS OF NON-CONSENSUAL SECURITY INTERESTS}

\section{Liens}

The majority of non-governmental liens ${ }^{172}$ fall within section 32 of the PPSA and will therefore obtain priority over prior and subsequent security interests. Section 32 does not encompass the innkeeper's lien because the innkeeper does not furnish materials or services in relation to the goods. The lien of the common carrier might also be excluded if section 32 is construed as requiring that the labour or services result in an enhancement or preservation of value. However, even in the absence of section 32 , both liens are entitled to priority over a prior security interest by virtue of the peculiar common law rule which gave the liens priority over property of third parties. ${ }^{173}$

Most statutory liens in favour of government or public bodies contain some form of priority language. There are two major categories of statutory priority rules that are found in Alberta. In the first category are provisions that indicate that a lien is to have priority over all charges and encumbrances, or words to a similar effect. ${ }^{174}$ The second category involves liens that are said to be a first lien or preferential lien against the property concerned. ${ }^{175}$

The majority of these statutory lien provisions have not been interpreted by the Courts. The outcome will depend upon the application of the interpretive rule favouring preexisting property rights. The statutes which create the statutory liens usually pre-date the Avco decision, and therefore exhibit many of the characteristics which resulted in a loss of priority. The statutes often provide that the lien has priority over all encumbrances,

171. Supra, note 169.

172. See the discussion, supra, at notes 123-139.

173. R. \& R. Cunningham Enterprises Lid. v. Vollmers, [1973] 4 W.W.R. 339 (Alta. S.C.) (Innkeepers Act does not displace the common law right to claim a lien against the property of a third party). Bank of Montreal v. 4l403I Ontario Ltd. (1983), 2 P.P.S.A.C. 248 (Ont. Dist. Ct.) (PPSA does not govern priority of innkeeper's lien and its priority against prior security interests is therefore governed by the common law rule). This common law priority does not extend to boarding house keepers or lodging house keepers which will be subordinate to prior security interests. See the discussion. supra, note 164.

174. See, for example, Crop Liens Priorities Act, R.S.A. 1980, c. C-34; Forests Act, R.S.A. 1980, c. F-16, s. 32; Hail and Crop Insurance Act, R.S.A. 1980, c. H-1, s. 18; Hospitals Act, R.S.A. 1980, c. H-11, s. 47; Municipal Taxation Act, R.S.A. 1980, c. M-31, s. 129; Wildlife Act, S.A. 1984, c. W-9.1, s. 9.

175. Irrigation Act, R.S.A. 1980, c. I-11, s. 151. 
but this leaves open the possibility that this will be interpreted to mean that the lien attaches only to the debtor's unencumbered interest and the priority over encumbrances will only operate in respect of subsequent encumbrances. However, there is some evidence that courts will be less inclined to apply a strict interpretive approach where the services secured by the lien have enhanced the value of the property subject to the lien. ${ }^{176}$ The same logic might be applied in respect of the lien created by the Forests Act,${ }^{177}$ since the debtor would not otherwise obtain the right to the timber.

A reference to a preferential lien is not sufficient to give the security interest priority over a prior security interest because this merely designates priority over unsecured creditors. ${ }^{178}$ The reference to a lien as a first lien might be regarded as ambiguous because it does not unequivocally provide that the lien has priority over prior security interests. However, there is some authority in Alberta to the effect that it is sufficient to create priority. ${ }^{179}$

\section{Rights of Distress}

\section{Landlord's Distress}

Section 19 of the Seizures Act provides the priority rules relating to a landlord's distress. This provision has been in effect in Alberta for many years, and was amended when the PPSA came into effect. ${ }^{180}$ It overrides the common law rule that all goods found on the leased premises are subject to distress by restricting the exercise of the right of distress to goods that are the property of the tenant or person liable for the rent. ${ }^{181}$ However, there are certain exceptions to this general rule. In particular, the landlord may distrain on goods that are subject to a security interest other than a purchase-money security interest in the goods as original collateral or as proceeds. ${ }^{182}$ Thus, a purchasemoney security interest will have priority over a landlord's distress, but other security interests will not. True leases for a term of more than one year and commercial consignments which are deemed to be security interests under the PPSA do not fall within the definition of a security interest under the Seizures Act. These interests will have

Royal Bank v. Erdman, [1986] I W.W.R. 733 (Sask. Q.B.) (thresher's lien has priority over prior s. 178 Bank Act security); Canada Trust Co. v. Cenex, [1982] 2 W.W.R. 361 (Sask. C.A.) (lien for work done in extraction of minerals has priority over a prior security interest). And see the discussion, supra, at notes 156-159.

R.S.A. 1980, c. F-16, s. 32.

Royal Bank of Canada v. 238842 Alla. Lid., supra, note 158 at 380.

Oliver Chemical Co. Ltd. v. Fischer (1963), 42 W.W.R. 269 (Alta. Dist. Ct.) (first and preferential lien status conferred upon Bank Act security sufficient to give it priority over the lien of the hail insurance board).

Supra, nole 32.

In appropriate circumstances this wording will extend to subtenants: Dexleigh Corp. v. O'Toole's Realty (Alberta) Lid. (1986), 52 Alta. L.R. (2d) 284 (Q.B.); Parson's Village Commercial Centre Lid. v. Red Fort Ins. Services Lid. (1987), 51 Alta. L.R. (2d) 186 (M.C.).

The specific inclusion of proceeds in s. 19(2)(b.l) overcomes an argument that was made (but rejected) in Canadian Imperial Bank of Commerce v. Marathon Realty Co. (1987), 7 P.P.S.A.C. 230 (Sask. C.A.). The equivalent Saskatchewan legislation made no reference to proceeds, and it was argued that the priority of a purchase-money security interest did not extend to the proceeds. 
priority over a right of distress because they obtain the advantage of the general rule that the right of distress may only be exercised against the goods of the tenant.

A secured creditor who does not have a purchase-money security interest may nevertheless obtain priority if the collateral is seized and removed from the premises before the landlord distrains against the goods. The seizure and removal of the goods prevents a priority competition from arising because the landlord's right of distress can only be exercised against goods located on the leased premises. ${ }^{183}$ It is less certain whether the secured party will obtain priority if the goods are seized by a sheriff but left on the debtor's premises under a bailee's undertaking. Prior to the PPSA, this practice was sufficient to give the secured party priority over the landlord because the goods were in custodia legis and therefore unavailable for distraint by the landlord. ${ }^{18-4}$ It is possible that the PPSA has altered this outcome. Section 58(14) of the PPSA provides that a seizure shall not affect the interest of a person who under any other law has priority over the rights of the secured party. There is an unfortunate ambiguity with this language. Under the law of distress, the landlord was not entitled to priority if the goods were held in custodia legis. In the absence of a statutory provision which provides that a seizure by a sheriff no longer attracts this characterization, it may be argued that the landlord does not have a right to distress under these circumstances. Regardless of the effect of section $58(14)$, it is clear that the in custodia legis principle is in need of review. ${ }^{185}$ The priority should not be determined on the basis of a first to grab rule. It appears that the in custodia legis principle does not apply where a tenant is placed in receivership. ${ }^{186}$

Under the pre-PPSA provisions of the Seizures Act, it was held that where a chattel mortgage was granted by someone other than the person who was the tenant at the time of the landlord's distress, the chattel mortgagee would have priority over the landlord. ${ }^{187}$

183.

Supra, note 29.

Melton Real Estate Ltd. v. National Arts Service Corporation Lud., supra, note 30; Hinton Realty Lud. v. Dumn and Edinger (1985). 37 Alta. L.R. (2d) 352 (M.C.); Bank of Nova Scotia v. Neufeld (1986), 40 Alta. L.R. (2d) 352 (Q.B.). In a case where a seizure on behalf of a secured creditor and a distress on behalf of a landlord were done concurrently, it was held that the proceeds from the seizures should be divided between the parties on a pro rata basis: Alberta Treasury Branches $v$. P.M.P. Properties Ltd. (1989), 67 Alta. L.R. (2d) 281 (Q.B.). The result seems odd. Whatever the merits of the in custodia legis principle enunciated in the above cases, the goods were not in custodia legis when seized by the landlord. As a result, the landlord should have received priority under $\mathrm{s}$. 19.

1xs. This view was expressed by Master Funduk in Canadian Life Assurance Co. v. Kupka, supra, note 60 .

18k. The in custodia legis principle is not applicable regardless of whether the receiver is privately appointed or court appointed: R. Walton, Kerr on the Law and Practice of Receivers, 16th ed., (London: Sweet \& Maxwell. 1983) at 139, 310; Holy Spirit Credit Union Lud. v. Golden Mile Toyota Ltd. (1980), 113 D.L.R. (3d) 285 (Man. C.A.); Re Grant's Heat and Power Ltd. (1983), 48 C.B.R. (N.S.) 258 (Sask. Q.B.). It seems logical that goods in the hands of a privately appointed receiver slrould not be considered to be in the custody of the law. It is less casy to justify this conclusion in respect of a court appointed receiver. The landlord must still obtain leave of the Court before distraining as the distress interferes with the possession of a court appointed receiver. See Household Trust Co. v. Leslie-Gowers Inc., supra, notc 61.

187. Calgary Brewing and Malting Co. Ltd. v. Martin and Co. (1915), 9 W.W.R. 563 (Alta. S.C.T.D.); Crystall v. Olsen. [1927] 2 W.W.R. 35 (Alta. S.C.T.D.). 
The legislation limited the landlord's right of distress to the goods of any person whose title was derived by transfer from the tenant. The requirement that the security interest be granted by the tenant has been omitted from the recent amendments in section 19(2)(b.1). A literal reading of the provision suggests that a landlord can claim priority even though the security interest in the goods was not granted by the tenant. This implies that a landlord could claim priority to goods found on the leased premises which are subject to a security interest granted by a third party and in respect of which the tenant has no interest. It is unlikely that the drafters of the legislation intended this outcome, but it appears to be the result unless the reference to security interest in section 19(2)(b.1) is construed to mean a security interest granted by the tenant.

\section{Other Statutory Distress Provisions}

There are a number of statutes which create a right of distress in Alberta. For the most part, these provisions fall within one of three categories. The first category involves distress provisions that are patterned after the priority provisions for landlords' distress. ${ }^{188}$ In the second category are provisions that create a right of distress, but provide little in the way of express priority provisions. ${ }^{189}$ In the third category are distress provisions that merely create a process for enforcing a claim, and are not meant to provide priority rules. ${ }^{190}$

Provisions in the first category will typically create the right to distress and indicate the property in respect of which the right may be exercised. These provisions tend to parallel the provisions of the Seizures Act in relation to the landlord's right of distress. Additional sections give priority to the holder of the distress rights even if the property susceptible to distress proceedings has already been subject to other enforcement proceedings. ${ }^{191}$ These provisions overcome the in custodia legis problem that arises where a seizure takes place before a landlord distrains. ${ }^{192}$

The primary problem with these provisions is that they were not amended upon the coming into force of the PPSA, and this may produce some interpretive difficulties. For example, the provisions typically draw a distinction between distress against goods subject to a conditional sales agreement and goods subject to a mortgage. The right of distress is given priority over a mortgagee, but is subordinate to the interest of the conditional seller because the right of distress operates only in respect of the buyer's interest. The problem is that these older categories of security agreements have lost their significance under the PPSA. These forms of agreements can still be used and will create a security

\footnotetext{
188. See, for example, Crop Payments (Irrigated Land Sales) Act, R.S.A. 1980, c. C-36, ss. 4 and 5; Drainage Districts Act, R.S.A. 1980, c. D-39, ss. 171-174; Municipal Taxation Act, R.S.A. 1980, c. M-31, ss. 128, 136-138.

189. See, for example, Irrigation Act, R.S.A. 1980, c. 1-11, s. 150.

190. Municipal Government Act, R.S.A. 1980, c. M-26, s. 309; Special Areas Act, R.S.A. 1980, c. S-20, s. 8; Threshers' Lien Act, R.S.A. 1980, c. T-4, s. 7.

191. See, for example, Municipal Taxation Act, R.S.A. 1980, c. M-31, s. 137; Drainage Districts Act, R.S.A. 1980 , c. D-39, s. 174.

192. Bank of Montreal v. International Polyurethane Co. Lid. (1981), 14 Alta. L.R. (2d) 389 (Q.B.); Royal Bank of Canada v. 238842 Alberta Lid., supra, note 158.
} 
interest that will be governed by the PPSA. However, it is common to find modernized forms of agreements which simply provide that the secured party is granted a security interest in the collateral. Section 73(2) of the PPSA provides an interpretive rule for these problems of translation. A reference to a mortgage or conditional sales agreement in an Act is deemed to be a reference to the corresponding kind of security interest under the PPSA. For modernized forms of security agreements which may not provide that the seller retains legal title to the goods, this means that a purchase money security interest in goods sold by the seller has priority over the right of distress. ${ }^{193}$

A good example of a distress right fitting within the second category is found in the Irrigation Act. ${ }^{194}$ The statute provides that an irrigation board may recover arrears owing to it by distress on any goods or any interest therein owned by the debtor and found on the land. The provisions of the Exemptions Act and the Seizures Act are incorporated by reference. This means that the same procedural requirements which apply to a landlord's right of distress will apply to an irrigation board. It is, however, unlikely that this is sufficient to incorporate the priority of the landlord over security interests. Section 19 of the Seizures Act cuts back the common law right of a landlord to distrain against goods of third parties, and therefore the reference to that statute does not have the effect of giving the board a right of distress against third parties. If an irrigation board has such a right it must be derived from the statute which gives it the right of distress. There is nothing in the Irrigation Act that provides that a board has the same right as a landlord to distrain ${ }^{195}$ or which suggests that the distress is available against the interest of third parties. Therefore, the right of distress operates only in respect of the debtor's interest in the goods.

The third category of distress is used simply to denote an enforcement process and is not intended to convey any priority rights. The priority of the claim is instead based upon some other category of non-consensual security interest that is created by the statute. For example, the Thresher's Lien Act creates a lien on the crops which is given priority over all security interests ${ }^{196}$ and which is enforced through a right of distress. The more difficult issue concerns statutes which create a lien, but also incorporate distress provisions from other statutes that also contain priority rules. The question is whether the reference to distress is meant to incorporate the enforcement process only or whether it is meant to also incorporate the priority rules associated with the distress. For example, a lien for public utility charges is said to be a preferential lien that may be collected in the same manner as municipal taxes. ${ }^{197}$ In turn, the Municipal Taxation Act allows distress to be made for outstanding taxes, and provides priority rules in relation to such a distress. ${ }^{198}$

\footnotetext{
193. See Cuming \& Wood, Alberta Personal Property Security Act Handhook, supra, note 169 at 353.

194. R.S.A. 1980 , c. I-11, s. 150.

195. Compare the Manitoba statute discussed in Canadian Imperial Bank of Commerce v. 64576 Man. Ltd., supra, note 60 which gave Manitoba Hydro the same right to distress as a landlord.

1\%. R.S.A. 1980 , c. T-4, ss. 2 and 7.

197. Municipal Government Act, R.S.A. 1980, c. M-26, s. 309.

198. Municipal Taxation Act, R.S.A. 1980, c. M-31, s. 128. Although the priority rules in s. 128 were not amended when the PPSA came into force in Alberta, they are worded in a way that should still allow them to be applied to security interests under the PPSA. They would appear to subordinate most forms of PPSA security interests, except purchase-money security interests involving sale
} 
In Saskatchewan it has been held that this incorporates both the enforcement proceedings and the priority rules of the other statute. ${ }^{199}$

\section{Statutory Charges and Security Interests}

A sharp distinction is usually not drawn between statutory liens and statutory charges. Indeed, some statutes create an interest referred to as a lien and charge on the property. ${ }^{200}$ The only significance in the terminology is that a non-consensual security interest in the form of a charge may attract the argument that it is a floating charge. ${ }^{201}$

The provisions that create statutory charges and deemed security interests in the Employment Standards Act and the Workers' Compensation Act represent a new generation of statutory priority rules. The statutory language is born of the experience gained from previous generations of legislation that unsuccessfully attempted to subordinate consensual security interests. ${ }^{202}$ Unlike many other provisions in Alberta covering non-consensual security interests, the provisions in these two Acts have been amended to take into account the changed terminology that results from the passage of the PPSA. The statutes make it absolutely clear that the interest is intended to have priority over prior security interests. The Employment Standards Code provides a limited exception which gives a prior purchase-money security interest priority provided that it is properly registered within the time periods set out in the PPSA. ${ }^{203}$ The solicitor's

contracts.

149. Royal Bank of Canada v. 238842 Alta. Lid., stupra, note 158. In Re Moumtstephen Construction Lid., supra, note 103 it was held that it is by virtue of the lien rather than the enforcement proceedings that the claim is secured for the purposes of bankruptcy law, but this does not address the question whether the enforcement proceedings will attract the additional priority advantages or whether it was intended to incorporate only the procedural aspects of the statute creating the right to distress. See, for example, Municipal Government Act, R.S.A. 1980, c. M-26, s. 308.

201. See discussion, supra, at note 103.

202. The priority provisions are found in s. 113 of the Employment Standards Code, S.A. 1988, c. E-10.2 and s. 126 to 127.1 of the Workers' Compensation Act, S.A. 1981, c. W-16. Earlier attempts at subordinating consensual security interests had failed under both Acts. The previous priority provision in the employments standards legislation gave priority to "preferred, ordinary and general creditors." In Canadian Commercial Bank v. Bird Oil Equipment Ltd. (1985), 38 Alta. L.R. (2d) 102 (Q.B.) this phrase was interpreted as excluding secured creditors. The previous provision in the Workers' Compensation Act was interpreted as giving the Board a floating charge only, placing the Board in a very poor position in any priority contests. See Workers' Compensation Board v. The Queen, supra, note 42; Toronto Dominion Bank v. Associated Decorators (1979), 23 A.R. 583 (Q.B.). The drafters of the legislation clearly set out to reverse the previous jurisprudence on priority rules for non-consensual security interests. The Employment Standards Code creates a security interest to protect wages owed by an employer. This deemed security interest is said to be in the property of an employer, whether or not such property is subject to other security interests, and regardless of when such security interests were created. The charge under the Workers' Compensation Act is said to be a fixed, specific and continuing charge on the property of the employer or used by the employer in its industry. It is granted priority over virtually all claims and security interests whenever created. Courts in Alberta have been prepared to accept the priority of the Board's charge over even preexisting security interests: Alberta Treasury Branches v. Invictus Financial Corporation Ltd. (1986), 42 Alta. L.R. (2d) 181 (Q.B.); Royal Bank of Canada v. Canadian Aero-Marine Industries Inc. (1989), 67 Alta. L.R. (2d) 172 (Q.B.). 
charge provided under Rule 625 of the Alberta Rules of Court has also been held to take priority over pre-existing interests. ${ }^{204}$

\section{Deemed Statutory Trusts}

The provisions creating deemed statutory trusts in respect of source deductions do not contain an express priority rule. The statutes provide that the debtor is deemed to hold the money collected in trust and further provide that the debtor is deemed to keep the money separate and apart even if it has not actually been kept separate and apart. Although the Supreme Court of Canada has held that a deemed trust will not be effective in bankruptcy unless the money is identifiable or traceable, ${ }^{205}$ the deeming provision is fully effective outside of bankruptcy. ${ }^{206}$ A time of attachment analysis is used to determine priorities, and the deemed trust will therefore have priority only over security interests which arose after the trust was deemed to come into existence. Prior to the coming into force of the PPSA this analysis resulted in the subordination of the deemed trust to prior fixed security interests. ${ }^{207}$ However, the deemed trust took priority over an uncrystallized floating charge because the charge did not specifically attach to the assets until crystallization occurred.

Under the PPSA the notion of a floating security interest has been abolished. A security interest, including a floating charge, attaches to the debtor's existing property when the security agreement is executed and value is given and will thereafter attach to after-acquired property as soon as the debtor obtains rights in it. On this analysis it might seem inevitable that the deemed trust will now be routinely subordinated to all security interests except for the relatively rare case where the security interest comes into existence after the deemed trust arises. In fact, this has not occurred. In Royal Bank of Canada v. G.M. Homes Inc. ${ }^{208}$ the Saskatchewan Court of Appeal subordinated a pre-existing security interest to statutory trusts for wage deductions under the Canada Pension Plan Act and the Unemployment Insurance Act. The security agreement contemplated that the debtor would pay its employees in the ordinary course of business. Once the wages were paid they became the property of the employees who took the wages free from the security agreement. The trust attached to the money of the employees that was held back

Under R. 625 a lawyer may be entitled to a charge on propeny recovered or preserved. It has been held that the charge takes priority over an assignment of book debts and previously registered writs: McCready Products Lid. v. Sherwin-Williams Co. of Canada Ltd. (1986), 43 Alta. L.R. (2d) 269 (Q.B.), rev'd in part on other grounds 45 Alta. L.R. (2d) 228 (C.A.); Atkins v. Carraher (1987), 76 A.R. 249 (M.C.). These decisions were based on the wording of the provision which states that the charge is on "the property recovered or preserved" rather than in the debtor's interest in such property, and upon the fact that the solicitor's actions could be said to have benefited creditors by preserving the value of the property. British Columbia v. Henfrey Samson Belair, [1989] 2 S.C.R. 24.

Dauphin Plains Credit Union Lid. v. Xyloid Industries Ltd., supra, note 50; Roynat Inc. v. Ja-Sha Trucking \& Leasing Lrd., [1992] I W.W.R. 541 (Man. Q.B.), aff'd [1992] 2 W.W.R. 641 (Man. C.A.).

Re Stephen's Welding Ltd., (1980), 116 D.L.R. (3d) 543 (Alta. Q.B.) (assignment of book debts took priority over statutory trusts created by Canada Pension Plan Act and Unemployment Insurance Act). Supra, note 169. 
and the deemed trust provision relaxed the usual tracing requirements and permitted the trust to be asserted against the business assets.

This theory makes most sense in the case of a sales tax or other similar tax in which the money to be remitted is collected from a third party. In this case it is clear that the money collected by the debtor is subject to a trust, and the deeming provision allows the trust to be claimed against the assets even though it might not otherwise have been possible to trace the money. However, in the case of pay-roll deductions, the application of this theory becomes artificial. It assumes that the employer pays the full amount to the employee and then deducts some of the money which it then holds in trust. This process is wholly fictional. ${ }^{209}$ The fiction becomes even greater in the case of the deemed trust created by the Employment Standards Code. ${ }^{210}$ The debtor is deemed to hold wages accruing due in trust even though the wages have not been paid at the time the trust is deemed to arise.

A different justification for the priority of a deemed trust was developed in Re Windsor Packing Co. Ltd. ${ }^{21}$ The Ontario Court of Appeal held that a trust for vacation pay under the Employment Standards Act took priority over a pre-existing security interest on the theory that to hold otherwise would allow an employer to contract out of the Employment Standards Act. ${ }^{212}$ The security agreement took the form of a general security agreement and the Court noted that it permitted the debtor to pay its employees. This reasoning clearly signals a reversal of the strict interpretive approach in Avco in favour of a broader policy approach in favour of unpaid wage claimants.

The G.M. Homes and Windsor Packing decisions do not subordinate all prior security interests to the deemed trusts. Both decisions make it clear that they operate only in respect of security agreements which create a security interest in the entire undertaking and permit the debtor to pay its employees in the ordinary course of business. Both decisions are therefore premised on the notion that the authorization granted to the debtor to pay employees allows the deemed trust to operate on the debtor's encumbered assets. This idea is developed further by the Manitoba Court of Appeal in Roynat Inc. v. Ja-Sha Trucking \& Leasing Ltd. ${ }^{213}$ The Court specifically grounded its decision in favour of a deemed trust on the basis of such an authorization.

See A.E. Hardy, supra, note 98 at $123-4$ in which the author concludes that the case is wrongly decided for this reason.

S.A. 1988, c. E-10.2, s.113(1).

(1986), 58 C.B.R. (N.S.) 1 (Ont. C.A.).

It should be noted that under the Ontario Employment Standards Act, R.S.O. 1980, c. 137, s. 15, a trust for vacation pay is created, and in addition vacation pay becomes a lien on the employer's property. The Court in Windsor Packing referred primarily to the trust crealed by s. 15. In Armstrong v. Canadian Admiral Corp. (1987), 42 D.L.R. (4th) 189 the Ontario Court of Appeal subordinated s. 178 Bank Act security to a claim for vacation pay, referring primarily to the lien created by s. 15 of the Employment Standards Act. It noted that the lien attached to after-acquired property of the debtor immediately on its acquisition. The Bank's s. 178 security in after-acquired property could attach only subject to the lien.

Supra, note 206. 
We are of the opinion that these decisions do not provide a satisfactory basis for granting priority to the deemed trust. The approaches in G.M. Homes and Ja-Sha Trucking are premised upon a fictional payment and holding back of funds. The Windsor Packing approach provides no guidance on when, as a matter of policy, the protection of the non-consensual security interest should override a pre-existing security interest. It is preferable to recognize that, with the exception of money collected from a third party, deemed trust provisions alone are not effective in giving a non-consensual security interest priority over a pre-existing security interest. If it is intended that the deemed trust should have priority over prior security interests, this should be specified in an express priority rule.

\section{Statutory Demands}

Statutory demand provisions create a procedure through which a claimant may demand payment from a third party of money that would otherwise be payable to the debtor. A statutory demand procedure is similar to the garnishment remedy of unsecured creditors under provincial law. It will not by itself give the claimant a proprietary interest in the account owing, nor will it give the claimant priority over a prior security interest in the account. The statutory demand provisions in the Income Tax Act and other federal statutes were amended in 1987 in an attempt to give Revenue Canada priority over prior security interests. ${ }^{214}$ The controversy produced by these amendments provides an excellent example of the themes previously discussed.

The 1987 amendment to section 224 of the Income Tax Act broadened the scope of the demand and provided that it could be used to require the payment to Revenue Canada of money that would otherwise be payable to a secured creditor who had a right to payment of the money by virtue of a security interest in the account. The provision did not create a charge or other non-consensual security interest in the money or expressly state a priority rule in favour of Revenue Canada. Courts in Saskatchewan and Nova Scotia decided that although a priority rule was not expressly stated, there was no ambiguity because it could be inferred from the legislation that Revenue Canada was intended to have priority. ${ }^{215}$ However, the dominant view $^{216}$ has been to apply the strict interpretive approach in Avco and hold that the statutory demand is ineffective against a prior security interest because of the absence of unambiguous language to that effect. In other words, although the statute gave Revenue Canada the right to obtain custody of the money, there was nothing in the statute that gave Revenue Canada priority to it.

The statutory demand provisions in the Income Tax Act were again amended in 1990 to provide that the money paid pursuant to the statutory demand becomes the property of

\footnotetext{
214. S.C. 1987 , c. 46 , s. 66 , adding s. $224(1.2)$.

215. Royal Bank v. Saskatchewan Pou'er Corp., [1991] I W.W.R. I (Sask. C.A.); Touche Ross Lul. v. Minister of National Revemue (1990), 71 D.L.R. (4th) 648 (N.S.T.D.).

216. Lloyds Bank Canada v. International Warranty Co. Lid. (1989), supra, note 149; Concorde International Travel Inc. v. T.I. Travel Services (B.C.) Inc. (1990), 72 D.L.R. (4th) 405 (B.C.C.A.); Pembina on the Red Development Corp. v. Triman Industries Lid., [1991] 6 W.W.R. 481 (Man. C.A.); Toronto-Dominion Bank v. Canada, [1990] C.T.C. 542 (Fed. Ct. T.D.).
} 
Her Majesty and shall be paid to Revenue Canada in priority to any security interest. ${ }^{217}$ This language is sufficient to give Revenue Canada priority over a prior security interest. $^{218}$

\section{EFFECT OF BANKRUPTCY}

The resolution of a priority competition between a PPSA security interest and a nonconsensual security interest is further complicated if the debtor goes into bankruptcy. The normal provincial priority system may be superseded by a fundamentally different scheme governed by federal bankruptcy law. The original bankruptcy statute did not anticipate the rapid modern growth of the non-consensual security interest. This lacuna in the legislative scheme produced an astonishing volume of litigation as courts attempted to create a workable set of principles. A coherent body of law eventually emerged after the Supreme Court of Canada resolved several controversial issues.

In 1992, Parliament enacted an amending statute which finally broke the log-jam in the reform of Canadian bankruptcy law. Bill C-22 introduced important new changes that affect the priority of non-consensual and security interests. ${ }^{219}$ These changes did not completely replace the old approach. The amendments create special rules covering Crown claims. Therefore, the older analysis continues to apply to other kinds of nonconsensual security interests.

We will begin with a discussion of the approach under the original bankruptcy statute. We will then examine the 1992 amendments, and analyze the theory of priority underlying these changes.

\section{A. THE ORIGINAL APPROACH OF THE BANKRUPTCY ACT}

Bankruptcy is a mechanism through which unsecured creditors proceed collectively against the assets of the debtor. It differs from the provincial judgment enforcement system in that realization is undertaken by a single person (the trustee in bankruptcy) on behalf of all the creditors rather than by each of the unsecured creditors separately. An assignment in bankruptcy or petition for a receiving order suspends the collection measures of the unsecured creditors. Thereafter, all collection measures must be undertaken by the trustee in bankruptcy. ${ }^{220}$

Secured creditors are dealt with on an altogether different footing under bankruptcy law. A secured party retains its right to enforce its security interest in the collateral upon a default by the debtor. The assets subject to a security interest therefore will not be

217.

S.C. 1990, c.34, ss. 1(1)-(3), amending s. 224(1.2). To the same effect, see Excise Tax Act, R.S.C. 1985, c. E-15, s. 317, en. S.C. 1990. c. 45, s. 12.

21x. Berg v. Parker Pacific Eymipmemt Sales, [1991] C.T.C. 442 (B.C.S.C.).

210. 3rd Sess., 34 Parl., 40 Eliz. 1991. Bill C-22 was passed by the House of Commons on June 10, 1992 but does not come into force until proclaimed by order of the Governor in Council. The statute is renamed the Bankrupicy and Insolvency Act.

Bankruptcy Act, R.S.C. 1985 , c. B-3, s. 70(1). 
subject to distribution in bankruptcy, except to the extent that a surplus remains after the claim of the secured party is fully satisfied.

Under the bankruptcy statute, a creditor who has a non-consensual security interest falls within the definition of a "secured creditor."221 For example, a repairer who claims a possessory lien is considered to be a secured creditor. ${ }^{222}$ The repairer may therefore proceed to enforce the non-consensual security interest and apply the proceeds solely in satisfaction of the repairer's claim. The priority of the non-consensual security interest is governed by provincial law, and is not affected by bankruptcy.

The outcome is different if the claim secured by the non-consensual security interest happens to be one mentioned as a preferred claim in section 136 of the Bankruptcy Act. This section creates a hierarchy of ten classes of claims which are given a preference on distribution over the claims of the general creditors. Each class of preferred claim must be fully satisfied before the next class of preferred claim receives anything. The classes of preferred claims include claims for wages by unpaid employees, claims for municipal taxes that do not constitute a preferential lien or charge against real property, and claims by landlords for arrears of rent. Claims under workers' compensation, income tax and unemployment insurance legislation, and any other Crown claim were originally included as preferred claims. However, the 1992 amendments remove their designation as preferred claims.

The Supreme Court of Canada has held that the priority of a preferred claim is to be determined by section 136, and that a claimant can not assert a claim as a secured creditor on the basis of a non-consensual security interest created under provincial law..$^{\mathbf{2 2 3}}$ Although the non-consensual security interest remains valid outside of bankruptcy, section 136 governs the distribution in bankruptcy. This approach accepts that there may be a difference between the priorities existing under provincial law and the priorities in bankruptcy. Secured parties have exploited this feature by invoking bankruptcy in order to obtain the benefits of this inversion of priorities. ${ }^{224}$ A secured creditor may avail itself of the bankruptcy process for the sole purpose of enhancing its position, and this does not constitute a sufficient reason for the Court to dismiss a petition for a receiving order. $^{225}$ The troublesome feature of this approach is that it does not accord with the underlying rationale for the existence of a bankruptcy system. Bankruptcy is an enforcement remedy under which unsecured creditors collectively assert their claims against the debtor. Secured creditors were never brought within this system; for the most part they enforced their security interests against the collateral outside of the bankruptcy system. It is difficult to understand why they should be able to invoke bankruptcy to enhance their claims at the expense of unsecured creditors for whom the bankruptcy system was designed. 
A similar controversy arose as to the efficacy of deemed statutory trusts in bankruptcy. Section 67(a) of the Bankruptcy Act provides that property held by the bankrupt in trust for another person does not form part of the assets distributable to the creditors. Some courts held that a deemed statutory trust operated so that the property subject to the trust never formed part of the bankrupt's estate. ${ }^{226}$ Other courts disagreed and held that section 67(a) only applies to true trusts in which the trust property is identifiable or traceable. ${ }^{227}$ The Supreme Court of Canada in British Columbia v. Henfrey Samson Belair Ltd. ${ }^{228}$ held that the use of a deemed statutory trust will not alter the scheme of distribution in bankruptcy of claims that fall within section 136. The Court decided that section 67(a) must be confined to true trusts and does not apply to deemed trusts that lack the common law attributes of a trust. If the money collected for tax is identifiable or traceable, it is exempt from distribution by reason of section 67(a). If it is not identifiable or traceable, the deemed trust provision is ineffective and the scheme of distribution is governed by section 136 .

There was initially some uncertainty whether the federal statutes creating deemed statutory trusts were effective in bankruptcy. ${ }^{229}$ The federal statutes were subsequently amended so as to provide that the deemed trust operated notwithstanding any provision in the Bankruptcy Act. In other provinces, the deemed statutory trust was primarily employed in relation to the collection of provincial taxes. The major impact of the Henfrey decision in Alberta was the invalidation in bankruptcy of the deemed trust in favour of employees for unpaid wages.

Many of the cases assume that a provincial non-consensual security device that falls within section 136 is invalid. As a result, secured parties are the ultimate beneficiaries of the inversion of priorities. A competing theory is that a non-consensual security interest is not rendered void by virtue of section 136, but is only inoperative as against the trustee in bankruptcy. The trustee in bankruptcy may assert the non-consensual security interest against the secured party. The resulting fund is then distributed pursuant to the scheme set out in section 136. This approach would discourage the practice of secured creditors invoking bankruptcy, since their priority position would be the same as in a non-bankruptcy situation. The bankruptcy would only affect the manner in which the fund was distributed among the preferred creditors. The British Columbia Court of Appeal rejected this view and held that the effect of section 136 was to prevent a provincial legislature from conferring any greater priority in respect of the preferred claims. ${ }^{230}$ The issue has not yet been considered by the Supreme Court of Canada. ${ }^{231}$ Lumber Co. Lid. (1985), 56 C.B.R. (N.S.) 206 (Sask. C.A.).

229. In Attorney-General of Canada v. Samson Belair Lid., [1985] 3 W.W.R. 651 (B.C.C.A.) it was held that the deemed trust in respect of unemployment insurance deductions was subject to distribution in bankruptcy as merely a preferred claim pursuant to the scheme of distribution in $\mathrm{s} .107$ [now s. 136), but that the deemed statutory trust in favour of Canada Pension Plan deductions was effective. 
However, the analysis in the major decisions suggests that the non-consensual security interests "cease to be of any force and effect."232 This supports the view that secured creditors get the benefit of an inversion of priorities.

One other technique has been devised by the provincial legislatures in attempting to maintain the priority of a non-consensual security interest in bankruptcy. It involves a direct attack on the validity of the competing security interest. Section 126.1(2) of the Worker's Compensation Act ${ }^{233}$ provides a good example of this technique. The provision renders a PPSA security interest void as a against the Board. The operation of this provision in a bankruptcy is uncertain. Provincial legislation which subordinates a provincial security interest has been held to be inter vires. ${ }^{2.34}$ However, these statutes subordinate a security interest to a trustee in bankruptcy as part of a more general scheme that subordinates unperfected security interests to creditors and other third parties. The sole purpose of the Worker's Compensation Act provision is to elevate the priority status of the Board's claim in a bankruptcy. It is therefore likely that the provision will be viewed as a colourable attempt to interfere with the scheme of distribution set out in the bankruptcy statute.

\section{B. THE 1992 BANKRUPTCY AMENDMENTS}

Bill C-22 contains amendments which significantly change the priority status of nonconsensual security interests in favour of the Crown. The original bill would have also enacted the Wage Claim Payment Act. ${ }^{235}$ Under this Act, claims of employees for unpaid wages would have been deleted from the list of preferred claims in section 136. In its place, employees would receive the benefit of an insurance scheme funded by a tax on employers. The Wage Claim Payment Act was dropped after businesses complained

231. The issue was raised in British Colımbia v. Henfrey Belair Lud., supra, note 205 but was not decided by the Court because it had not been raised in the courts below or in the application for leave, and it concerned parties who were not present on the appeal.

Bank of Montreal v. Titan Landco Inc., supra, note 230 at 314: Re Black Forest Restaurant Ltd. (1981), 121 D.L.R. (3d) 435 (N.S.T.D.) at 448, quoted with approval by the Supreme Court of Canada in Re Deloitte. Haskins \& Sells v. Workers' Compensation Board, supra, note 223. And see J.S. Ziegel, "The Supreme Court of Canada Scuttles the Deemed Trust in Bankruptcy" (1989). 15 C.B.L.J. 498 at 509-511.

233. R.S.A. 1980, c. W-16, am. S.A. 1984, c. 68, s. 35, S.A. 1990, c.39, s. 20.

234. Paccar Financial Services Lid. v. Sinco Trucking Lid., [1989] 3 W.W.R. 481 (Sask. C.A.); Re Hannah (1988), 8 P.P.S.A.C. 181 (Ont. S.C.); Re Haasen (1992), 8 O.R. (3d) 489 (Gen. Div.). Some commentators have argued that the provincial legislation interferes with the scheme of distribution set out in s. 136 of the Bankruptcy Act and should be inoperative for the same reasons that provincial law can not raise the priority status of preferred claimants. See A.J. Roman \& M.J. Sweatman, "The Conflict between Canadian Provincial Personal Security Acts and the Federal Bankruptcy Act: The War is Over" (1992), 71 Can. Bar Rev. 77. We think that this analysis suffers from a fundamental flaw. Secured creditors are not within the scheme of distribution set out in $\mathbf{s}$. 136. Secured creditors realize on their security outside of the bankruptcy system of distribution, and therefore the cases dealing with s. 136 are of no relevance. 
that they could not afford to pay the premiums needed to create a $\$ 70$ million fund to pay workers. ${ }^{236}$

Bill C-22 amends the Bankruptcy Act by adding a provision that codifies the position taken by the Supreme Court of Canada ${ }^{237}$ on the validity of deemed statutory trusts. The section provides that property shall not be regarded as held in trust for the purposes of section 67 of the Bankruptcy Act unless it would be so regarded in the absence of that statutory provision. ${ }^{238}$ This provision does not apply to the deemed statutory trusts in the Income Tax Act, the Canada Pension Plan, the Unemployment Insurance Act and provincial legislation which creates a deemed trust which has as its sole purpose ensuring the payment to the provincial Crown of amounts required by the provincial legislation to be deducted or withheld. ${ }^{239}$

Bill C-22 also amends the Bankruptcy Act by removing Crown claims as preferred claims under section $136 .{ }^{240}$ A provision is added to the effect that all provable claims of the Crown rank as unsecured claims. ${ }^{241}$ This would tend to produce a somewhat larger dividend in favour of general creditors, because Crown claims would no longer rank as preferred creditors. ${ }^{242}$

This subordination is subject to three exceptions. First, it applies only to nonconsensual security interests in favour of the Crown. Other claims, such as the landlord's right of distress, continue to be affected by the scheme of distribution in section 136 . Second, the subordination does not apply to the statutory demand as set out in section 224(1.2) of the Income Tax Act. ${ }^{243}$ Third, the subordination will not apply if the nonconsensual security interest is registered before the bankruptcy proceedings have been initiated. $^{244}$ If the registration requirement is met, the non-consensual security interest will have the status of a secured creditor for the purposes of the Bankruptcy Act and will rank above the preferred creditors set out in section 136. ${ }^{245}$ The legislation provides that a non-consensual security interest that is so registered is subordinate to security interests that are perfected before the registration. ${ }^{246}$ The registration requirement is subject to an important qualification: it validates the non-consensual security interest only

The Globe and Mail (24 June 1992) B-2. The issue of wage protection will be referred to a joint Commons-Senate committee for "further study."

237. British Columbia v. Henfrey Samson Belair Lud., supra, note 205.

238. Bill C-22, s. 33, adding new s. 67(2).

239. Bill C-22, s. 33, adding new s. 67(3).

280. Bill C-22, s. 54.

241. Bill C-22, s. 39 (replacing ss. 86 and 87 of the Bankruptcy Act), new section 86(1).

242. The amount by which the general creditors would benefit is likely to be very small. An empirical study found that the abolition of Crown claims would result in a 7\% recovery of the value of claims instead of a recovery of $5 \%$ of the value of claims. See J.S. Ziegel, "The New Personal Property Security Regimes: Have We Gone Too Far" (1990), 28 Alta. L. Rev. 739 at 756.

243. Bill C-22, s. 39, new section 86(3).

24. Bill C-22, s. 39 new section 87(1).

245. Ironically, this may mean that wage earners are worse off under the amended Act. Before the amendment, wage earner claims ranked ahead of Crown claims under s. 136. Now, registered Crown claims will rank ahead of wage earners and other preferred claimants. 
to the extent of amounts owing at the time the registration was effected. ${ }^{247}$ The Personal Property Registry has already been modified so as to permit registrations in respect of Workers' Compensation Board claims. ${ }^{248}$

The bankruptcy amendments are premised on the view that registration of nonconsensual security interests in favour of the Crown is needed in order to give notice of the existence of the non-consensual security interest to secured creditors and other interested parties. ${ }^{249}$ The problem is conceived to be that of the "secret lien," and the proposed solution is to require public notification of it through registration in the same way that a registration requirement is imposed on secured creditors.

We are not convinced that the solutions which have been adopted for consensual security interests ought to be extended to all varieties of non-consensual security interests. A registry system is needed when there are many potential lenders and it is too costly for a searching party to make inquiries to determine if a security interest has been granted. ${ }^{250}$ The same logic does not necessarily apply in the case of certain nonconsensual security interests. For example, a province may decide that certain claims, such as claims in favour of a workers' compensation board, should have priority over security interests. It is difficult to see how a registration requirement provides any additional information to secured creditors. Even in the absence of a registration requirement, a secured creditor should know that its security interest will be subject to any unpaid assessments.

The bankruptcy amendments also appear to incorporate the view that a non-consensual security interest in favour of the Crown comes into existence when default occurs and that it is unfair to give this claim priority over prior interests. Registration validates the nonconsensual security interest only to the extent of obligations owing at the time of registration. This ensures that a security interest will have priority over a non-consensual security interest in the vast majority of cases. Registration of a non-consensual security interest prior to default is not effective because there is no obligation owing at the time of registration. However, when default occurs followed by registration of the nonconsensual security interest, the prior secured financing will already have been put in place and will be entitled to priority so long as the secured party properly perfected its interest.

In the case of the statutory charge in favour of the Workers' Compensation Board, it is more sensible to equate the device with a security interest created at the inception of the business and which secures a fluctuating balance of unpaid assessments in the same manner as a security interest may secure a line of credit. Even if one accepts the need for registration of non-consensual security interests, there is no good reason why the

Bill C-22, s.39, new s.87(2)(b).

Personal Property Security Regulation, Alta. Reg. 234/90, 342/91, s. 24.

This argument is made by W.A. Bogart, "Statutory Claims and Personal Property Security Legislation: A Proposal" (1983), 8 C.B.L.J. 129 at 161-172.

See D.G. Baird, "Notice Filing and the Problem of Ostensible Ownership" (1983), 12 J. of Legal Studies 53. 
registration should be effective only in respect of the obligation owing at the time of registration.

Our argument is not that Crown claims should invariably have priority over security interests. There has been a proliferation of non-consensual security interests in favour of the Crown and we are of the view that in many of these cases a special priority in favour of the Crown is unwarranted. A strong case might be made in favour of a priority for purchase-money security interests over the statutory charge. ${ }^{251}$ It may also be desirable to limit the extent of the priority of Crown claims. ${ }^{252}$ Our concern is simply that the bankruptcy amendments fail to come to grips with the issue. On its surface, the amendments appear to equate non-consensual security interests with consensual security interests. On closer examination, it becomes clear that the system has been designed in such a way that the non-consensual security interests will usually be subordinate to secured creditors. Furthermore, the conceptual integrity of the statute is seriously compromised by the exemption of the major non-consensual security interests in favour of the federal Crown. All that has been accomplished is that the ranking of provincial Crown claims has become less certain. If the Crown claimant registers before bankruptcy, it will be subordinate to prior perfected security interests but will have priority over all preferred and general creditors. If registration is not effected prior to bankruptcy, the Crown claimant will be relegated to the status of a general creditor.

\section{CONCLUSION}

We have developed a framework that can be used to resolve a priority contest between a PPSA security interest and a non-consensual security interest. However, it is our view that the current state of the law is unacceptable. The number of non-consensual security interests has grown dramatically over the past several decades. There is a near complete lack of consistency in the rules that govern the various interests. We have identified five different types of non-consensual security interests. Even within these five categories, there are significant differences in treatment which cannot be justified on any policy basis. Priority rules are often unclear, and courts have been unable to achieve a consistent or predictable approach. The situation is further confused by the existence of a separate set of federal rules that affect the priority of some classes of non-consensual security interests in the event of a bankruptcy.

The problems with the existing law on non-consensual security interests are reminiscent of the problems that beset chattel security law prior to the passage of the PPSA. Several categories of security interests co-existed under the old law, each of which was governed by different rules with no consistent overall approach. The PPSA sought to unify these categories through the creation of a single, rationalized system of law. Similarly,

The Employment Standards Code, S.A. 1988, c. E-10.2, s. 113 (2),(3) subordinates the deemed security interest to a prior purchase-money security interest but gives it priority over the charge of the Workers' Compensation Board. However, the charge created under the Workers' Compensation Act, S.A. 1981, c. W-16, s. 126 has priority over a purchase-money security interest. This is clearly a product of an incoherent theory of priority. 
legislative solutions are the only way to bring coherence to the area of non-consensual security interests. Any solution must confront a number of fundamental policy issues. It will be necessary to decide what kinds of claims should be protected by a nonconsensual security interest and what priority status should be accorded to the interest. The unabated growth in the use of non-consensual security interests should not be allowed to continue without a major rationalization of the system. 